\title{
Haklı Yahut Geçerli Fesih Nedeni Olarak İşyerinde Yaşanan Duygusal İlişkiler - Anayasa Mahkemesi ve Yargıtay Kararları Çerçevesinde Değerlendirmeler
}

\author{
Emotional Relationships in the Workplace As a Justified or Valid Reason \\ for Termination-Evaluations in the Framework of the Constitutional \\ Court and Supreme Court Decisions
}

Mustafa Alp $^{*}$ iD, Dilek Dulay Yangın ${ }^{* *}$ (D)

\section{öz}

İşyerinde yaşanan duygusal ilişkilerin işyerine olumsuz yansımaları ilişki sebebiyle çalışma ortamının huzurunu bozacak düzeyde dedikoduların ortaya çıkması, özellikle ast-üst konumunda çalışanlar arasındaki ilişkiye bağlı olarak kayırmacılık ve ilişkinin verdiği rahatlığa dayanarak işin görülmesinde özensizliklerin baş göstermesi, ilişki sırasında taraflar arasında ortaya çıkan tartışmaların işyerine yansıması, ilişskinin taraflarının eşleri yahut yakınlarının işyerine sirayet eden davranışları ve müdahaleleri sebebiyle çalışma düzeninin etkilenmesi gibi farklı şekillerde karşımıza çıkabilmektedir. $\mathrm{Bu}$ olumsuz etkilerin bir katalog halinde sınırlı bir biçimde sıralanması mümkün olmamakla birlikte Yargıtay’ın farklı tarihlerde verdiği kararlara konu olduğu ve haklı yahut geçerli fesih sebebi kapsamında değerlendirildiği görülmektedir. Anayasa Mahkemesi de 30/09/2020 tarihli 2017/14907 no.lu H.Ç ve 25/2/2021 tarihli 2018/1444 no.lu Esra Ünlü başvurularında işyerinde yaşanan duygusal ilişkilerin hangi durumlarda işverene fesih hakkı sağlayacağı konusunda özel hayatın gizliliği çerçevesinde değerlendirmeler yaparak çeşitli esaslar tespit etmiştir. Çalışmamızda işyerinde yaşanan duygusal ilişkilerin hangi durumlarda işverene fesih hakkı sağlayacağını Yargıtay kararları ve Anayasa Mahkemesi’nin H.Ç ve Esra Ünlü başvurusu ile verdiği kararlar çerçevesinde inceleyerek tespitlerde bulunmaya çalışacağız.

Anahtar Kelimeler: Özel Hayatın Gizliliği, Geçerli Fesih Sebebi Olarak İşyerinde Duygusal İlişkiler, Haklı Fesih Sebebi Olarak İşyerinde Duygusal İlişkiler.

* Prof. Dr., Dokuz Eylül Üniversitesi Hukuk Fakültesi, İş ve Sosyal Güvenlik Hukuku ABD, ORCID: 0000-0001-72994487.

** Doç.Dr., Manisa Celal Bayar Üniversitesi, İktisadi ve İdari Bilimler Fakültesi, Çalışma Ekonomisi ve Endüstri İlişkileri Bölümü, İs ve Sosyal Güvenlik Hukuku ABD, dilek.yangin@cbu.edu.tr ORCID:0000-0003-4702-5371

Sorumlu Yazar/Correspondence Author: Mustafa Alp

E-posta/E-mail: mustafa.alp@deu.edu.tr

Geliş Tarihi/Received: $\quad$ 15.08.2021

Kabul Tarihi/Accepted:

10.11.2021 


\section{ABSTRACT}

Negative reflections of emotional relationships in the workplace may appear different ways such as emergence of gossip at a level that will disrupt the peace of working environment due to the relationship nepotism due to the relationship between employees in the subordinate-superior position, negligence in the performance of the job based on the comfort of the relationship, the reflection of the discussions that arise between the parties during the relationship, affecting the working order due to the behaviors and interventions of the spouses or relatives of the parties to the relationship. Although it is not possible to list these negative effects in a catalog in a limited way, it is seen that they were the subject of the decisions of the Court of Cassation on different dates and were evaluated within the scope of justified or valid termination reason. The Constitutional Court, in the applications no. 2017/14907 dated 30/09/2020 and Esra Ünlü, dated 25/2/2021 no. 2018/1444, evaluated within the framework of the privacy of private life on the situations in which emotional relations in the workplace will give the employer the right to terminate and established various principles. In our study, we will try to determine in which cases emotional relations in the workplace will provide the employer with the right to terminate, within the framework of the Supreme Court decisions and the decisions of the Constitutional Court with the application of H.Ç and Esra Ünlü.

Keywords: The Privacy of Private Life, Emotional Relationships in the Workplace as a Valid Reason for Terminate, Emotional Relationships in the Workplace as a Justified Reason for Terminate,

\section{I.GiRiş}

İşin hayatın önemli bir unsuru olması ve işyerinde geçirilen zamanın uzunluğu nedeni ile birlikte çalışanların işyerinde arkadaşılı kurması ve duygusal ilişsilerin yaşanması normal bir durumdur. Ancak bu durumun işin yürütümünü yahut işyerindeki düzenini olumsuz etkilediği durumlar olabilmektedir. Kişilerin iletişim sağlayabilmesine olanak sağlayan en önemli alan olarak işyerlerinde yaşanan duygusal ilişkilerde kimi zaman her iki taraf da bekar, kimi zaman da taraflardan biri yahut her ikisi evli olabilmekte; bu tür ilişkiler işyeri dışında aile yapısını da önemli ölçüde etkileyebilmektedir. İşyerinde yaşanan duygusal ilişki sebebiyle çalışanların veriminin düşmesi, işe geç gelme yahut erken ayrılma, ilişki içerisinde bulunulan kişi ile yaşanan tartışmalar, işte hatalar yapma, işyeri ortamındaki duygusal ilişkilerin işyerinde dedikodulara sebep olması, gerçekleşmemiş olsa bile diğer çalışanlar üzerinde eşitsizlik yapıldığı yönünde algının ortaya çıkması ve husumete dayalı davranışların gelişmesi olumsuz etkiler arasında sayılabilir ${ }^{1}$. İşyerine olumsuz yansımaları olan duygusal ilişkilerin işverene fesih hakkı vereceği kabul edilmekle birlikte bu olasıllğıı baştan bu tür ilişkilerin iş ortamını olumsuz etkileyeceği yönünde sonuca varmayı haklı kılmayacağ 1 kabul edilmelidir. Diğer bir deyimle işverenin işçilerin birbirleri ile iletişim kurmasını engellemek amacıyla arkadaşlık ilişkisi yahut duygusal ilişkiler kurulması konusunda yasaklar getirmesi özel hayata müdahale olarak değerlendirilebilecektir ${ }^{2}$. Esasen iş hukukunun kendine özgü yapısı göz önünde tutulduğu vakit duygusal ilişki işyerindeki çalışma düzenini olumsuz etkilediği takdirde bu tür bir yasak bireysel iş sözleşmesinde yahut iç yönetmeliklerde yer almasa dahi işverene somut

1 Yusuf Yiğit, 'Yargıtay Kararları Işı̆̆ında İşyerinde Yaşanan Duygusal (Romantik) İlişkilerin İşverenin İş Sözleşmesini Fesih Hakkına Etkisi' (2020) 5 (1) Çankaya Üniversitesi Hukuk Fakültesi Dergisi 3778.

2 Ahmet Sevimli, İşçinin Özel Yaşamına Müdahalenin Sınırları (1.Baskı, Legal Yayıncılık 2006) 238 vd.. 
olayın özelliği çerçevesinde haklı yahut geçerli nedenle fesih hakkı doğuracaktır. İşyerinde yaşanan duygusal ilişkilerin evlilik ile sonuçlanması da söz konusu olup bu gibi hallerde kimi işverenlerin bireysel iş sözleşmesinde özel bir hüküm getirmek suretiyle yahut işyeri iç yönetmelikleri ile evlenen işçilerden birinin işten ayrılacağına dair hükümler getirdiği görülmektedir. Anılan hükümlerin kişilik haklarına ve özel hayata müdahale oluşturduğundan geçersiz olduğu kabul edilmelidir ${ }^{3}$.

Bununla birlikte konu sadece ülkemizde değil başka ülkelerde de tartışılmaktadır. 2005 yılında merkezi ABD’de bulunan ve Avrupa başta olmak üzere dünya çapında faaliyet gösteren Wal-Mart adlı şirket çalışanların iş dışında akşamları birlikte yemeğe çıkamayacakları yahut birbirinin işlerini etkileyecek nitelikte aşk ilişkileri yaşamalarının yasak olduğuna ve hatta diğer işçilerin bu durumu işverene ihbar etmekle yükümlü olduğuna yönelik kuralı da içeren etik yönetmeliği uygulamaya koymuştur. Bu kurala Almanya’da şirketin işyeri kurulu (Betriebsrat) dava açmış ve sözü edilen Yönetmelik Düsseldorf Eyalet İş Mahkemesi’nin 2015 yllında verdiği karara konu olmuştur. Eyalet İş Mahkemesi etik yönetmelikler ile çalışanlar arasındaki aşk ilişkisine dair getirilen bu düzenlemenin kişilik haklarının ihlali anlamına geldiğine, Federal Alman Anayasası’nın 1.maddesinin 2.fikrası ile çatıştığına, Wal-Mart'ın getirmiş olduğu bu yönetmelik ile çalışanlar arasında dezavantajlı durumların ortaya çıkmasına engel olmak amacıyla hareket edilmesinin durumu değiştirmeyeceğine karar vermiştir ${ }^{4}$.

İşletmelerin kurumsal politikaları kapsamında bazen sadece veya ek olarak yöneticiler ile astları arasında duygusal ilişkilerin yasaklandığı yahut duygusal ilişkide işyerinde aleni bir şekilde sevgi göstermek gibi davranışların kısıtlandığı da görülmektedir. Cinsel istismara karşı işyerinin en küçük toleransının olmadığı güvencesinin vurgulanması kaydı ile işyerindeki duygusal ilişkilerin engellenmemesi, işin yürütümüne ve işverenin menfaatlerine zarar vermediği sürece özel hayata saygı kapsamında kabul edilmesi yönündeki yaklaşım aşağıda incelenecek Anayasa Mahkemesi kararlarında da görüleceği üzere genel olarak benimsenmelidir ${ }^{5}$.

Kimi durumlarda yaşanan duygusal ilişki sebebiyle işçi kendi isteği ile işten ayrılmaktadır. Bu noktada işçi tarafından yapılan fesih İş Kanunu md.24 çerçevesinde haklı bir sebep olarak değerlendirilemeyecektir. Nitekim Yargıtay’n 19.06.2014 yllında verdiği karara konu olan olayda davacı iş sözleşmesinin haklı bir sebep olmaksızın işverence feshedildiğini ileri sürerken davalı, davacının işyerinde çalışan bayan işçi ile duygusal yakınlık oluşması sonucu şikayet ve işyerinde yaşanan olumsuzluk sebebi ile kendi isteği ile işten ayrıldığını ileri sürmüştür. Yargıtay 22. Hukuk Dairesi de dosya kapsamında tutulan tutanaklar ve tanık anlatımlarından iş sözleşmesinin davacı

3 Hediye Ergin, 'İşyerinde Gönül İlişkisinin İş Sözleşmesinin Feshine Etkisi' (2016) 35 Sicil İş Hukuku Dergisi 68 vd.

4 LAG Düsseldorf, Beschluss vom 14.11.2005 - $10 \mathrm{TaBV}$ 46/05; C Boyd: 'The Debate Over the Prohibition of Romance in the Workplace' (2010) 97 (2) Journal of Business Ethics Springer 326, 335; Kurt Pärli ve Jasmin Vögtli, 'Control and Sanction of Employees on the Basis of Conduct-A Question of Basic Labour (Human) Rights' (Spring 2020) Labour Law Journal 79; Mustafa Alp, Çalışanın İşvereni ve İş Arkadaşlarını İhbar Etmesi - Çalışanın Hukuka ve Etik Kurallara Aykırllıkları İfşa Hakkı ve İhbar Borcu - (Whistleblowing), (1.Bası, Beta Yayıncılık 2013) $240 \mathrm{vd.}$

5 Yiğit (n 1) 3780; Ergin Gönül İlişskisi (n 3) 68; Hakan Keser, 'İşçi Davranışları Kapsamında İş Sözleşmesinin Özel Hayat, Aile Hayatı ve Cinsel Yönelimler Sebebi ile İșverence Feshedilmesi’ (2017) 37 Sicil İş Hukuku Dergisi 21 vd. 
tarafından haklı sebeple feshedilmediğinin anlaşıldığını belirtmiş olup kıdem ve ihbar tazminatı talebinin reddedilmesi gerektiğine hükmederek yerel mahkeme kararını bozmuştur ${ }^{6}$.

Haklı yahut geçerli fesih sebebi olarak işyerinde yaşanan duygusal ilişkilerin yukarıdaki örnekten de görüldüğü üzere Yargıtay’n farklı tarihlerde verdiği kararlara konu olduğu görülmektedir. Yüksek Mahkeme iş güvencesi hükümlerinin yürürlüğe girdiği tarihe kadar olan dönem içerisinde (15 Mart 2003 öncesi) konuyu haklı fesih sebebi olarak ele alırken, bu dönemden sonra somut olayın özellikleri çerçevesinde haklı yahut geçerli fesih sebebi olarak değerlendirmiş ve zengin bir içtihat oluşturmuştur. Anayasa Mahkemesi ise işyerinde yaşanan duygusal ilişkilerin işverenin fesih hakkına ne şekilde etki edeceğini 30/09/2020 tarihli H.Ç başvurusu ve 25/2/2021 tarihli Esra Ünlü başvurusunda ele alarak özel hayata saygı kapsamında çeşitli kriterler geliştirmeye çalışmıştır. Biz bu çalışmamızda işyerinde yaşanan duygusal ilişkilerin iş ilişkisine etkisini Yargıtay’ın konuya ilişkin geliştirdiği içtihatları da göz önünde tutmak suretiyle anılan Anayasa Mahkemesi kararlarında tespit edilen esaslar ve doktrinde ileri sürülen görüşler çerçevesinde ele almaya çalışacağız.

\section{II. ÖZEL HAYATIN GIZLILIĞi VE KAPSAMI}

1982 Anayasası “Özel Hayatın Gizliliğgi” kenar başlıklı md.20 hükmü uyarınca "Herkes, özel hayatına ve aile hayatına saygı gösterilmesini isteme hakkına sahiptir. Özel hayatın ve aile hayatının gizliliğine dokunulamaz". Anayasa Mahkemesi'nin çeşitli tarihlerde yapılan bireysel başvurular neticesinde verdiği kararlarda özel hayatın tüketici bir tanımını yapmaktan kaçındığı ve kişilerin mesleki hayatlarının onların özel hayatlarıyla sıkı bir irtibatının olduğu ve meslek hayatına yönelik tedbirlerin ya da müdahalelerin söz konusu olduğu dava süreçlerinde özel hayata saygı hakkının gündeme geldiğinin yadsınamayacağını kabul ettiği görülmektedir ${ }^{7}$. Dış dünya ile irtibat kurulmasında önemli bir işlevi olan mesleki hayata özel hayatla ilgili birtakım nedenlerle müdahalede bulunulması ya da özel hayata ilişkin unsurlar gerekçe gösterilerek kısıtlayıcı yönde tedbirler alınması, bu tür uyuşmazlıkların özel hayat kapsamında ele alınması bakımından yeterlidir. Zira özel hayatlarına ilişkin nedenlerle kişilerin mesleki hayatlarına yönelen müdahalenin ya da bu kişiler hakkında gerçekleştirilen eylem veya idari ya da adli işlemlerin onların özel hayat alanlarını etkileyebileceği açıktır ${ }^{8}$.

Mahkeme’ye göre özel hayat kavramı eksiksiz bir tanımı bulunmayan geniş bir kavramdır. Bu kapsamda korunan hukuki değer esasen kişisel bağımsızlıktır. Özel hayata saygı gösterilmesini isteme hakkının kapsamının belirlenmesinde bireyin kişiliğini geliştirmesi ve gerçekleştirmesi temel alınmaktadır. Anılan hak herkesin istenmeyen bütün müdahalelerden uzak, kendine özel bir ortamda yaşama hakkına sahip olduğuna işaret etmekle birlikte kişiliğin serbestçe geliştirilmesiyle uyumlu birçok hukuki menfaati de içermektedir ${ }^{9}$.

6 Yargıtay 22.HD, 14638/18062, 19.06.2014 (Sinerji İçtihat ve Mevzuat Bilgi Bankası).

7 Anayasa Mahkemesi C.A. (3) [GK], B. No: 2018/10286, 2/7/2020, §88.

8 Anayasa Mahkemesi Tamer Mahmutoğlu, B. No: 2017/38953, 23/7/2020, § 85 (R.G. Tarih ve Sayı: 8/9/2020-31238)

9 Anayasa Mahkemesi Serap Tortuk, B. No: 2013/9660, 21/1/2015, \$\$ 31-35; Tevfik Türkmen [GK], B. No: 2013/9704, 3/3/2016, § 50; Ayşegül Çengel Kömür ve diğerleri, B. No: 2016/56228, 23/6/2020, $\$ 43$. 
Özel hayata saygı hakkı kapsamında korunan hukuksal çıkarlardan biri de bireyin mahremiyet hakkıdır. Özellikle mahremiyet alanında cereyan eden cinsel içerikli eylem ve davranışların özel hayata saygı hakkının kapsamında olduğunda kuşku yoktur. Bu yönüyle özel hayat, öncelikle bireylerin kendi bireyselliklerini geliştirebilecekleri ve diğer kişilerle en mahrem ilişkilere girebilecekleri özel bir alana işaret etmektedir ${ }^{10}$. Mahkeme’nin M.K başvurusunda da belirttiği üzere başvurucu tarafından alenileştirilmeyen, bireyin mahrem alanı içerisinde kalan ve mesleki hayatına etkisi ikna edici gerekçelerle ortaya koymayan eylem ve davranışlar özel hayatın gizliliği kapsamında korunmalıdır ${ }^{11}$. İleride değinilecek olan Esra Ünlü ve H.Ç başvurusunda ifade edildiği üzere işyerinde yaşanan duygusal ilişkilerin, bireylerin özel hayatının kapsamına dahil olabilecek mahrem alandan çıııp çalışma düzenine olumsuz bir biçimde etki etmesi ve bu etkinin işyerinin kapasitesi, işçinin ifa ettiği görevi, sicili, ilişkinin kim tarafından alenileştirildiği gibi hususlar gözetilerek değerlendirilip yeterli ve ilgili gerekçe ile açıklandığı ayrıca oluşan bu olumsuzluklar nedeniyle iş akdinin sürdürülmesinin işverenden beklenemeyeceği hususlarının işveren tarafından ortaya konulduğu hallerde işverenin fesih hakkından bahsedilmesi mümkün olabilecektir. Bununla birlikte Anayasa Mahkemesi'nin geliştirdiği yaklaşım ile Yargıtay’ın farklı tarihlerde verdiği kararlarda ortaya koyduğu yaklaşım farklılık arz etmekte olduğundan bu ayrışmanın doktrinde ileri sürülen görüşler de göz önünde tutularak ayrı bir başlık altında incelenmesi gerekmektedir.

\section{BIREYLERIN ÖZEL HAYATI KAPSAMINA GIREBILECEK MAHREM ALANDAN ÇIKAN DUYGUSAL ILIŞKILERININ IŞ iLIŞKISINE ETKILERi}

\section{A. iş SÖZLEŞMESININ FESHI BAKIMINDAN GENEL DEĞERLENDIRME}

Örgüt psikolojisi içerisinde bir işyerindeki iki çalışanın, karşılıklı çekimlerini birbirlerine açıkça söylediklerinde ve flört ya da herhangi bir yakın ilişki şeklinde romantik duygularını fiziksel olarak ifade ettiklerinde bu tür bir yakınlaşma "işyeri romantizmi” ya da "örgütsel romantizm" olarak nitelendirilebilmektedir ${ }^{12}$. Duygusal ilişki evli yahut bekar işyerinde çalışanlar arasında yaşanabileceği gibi müşteri, çalışanlardan birinin akrabası veya eşi ile çalışan arasında da ortaya çıkabilir.

İşyerinde yaşanan duygusal ilişkilerin Yargıtay tarafından çeşitli tarihlerde verilen kararlarda "gönül ilişkisi” olarak adlandırıldığı da görülmektedir ${ }^{13}$. Yüksek Mahkeme’nin duygusal ilişkilerin çalışma düzenine etkisi bakımından somut olayın özellikleri çerçevesinde İş Kanunu md.18 kapsamında geçerli sebeple fesih yahut İş Kanunu md.25/II çerçevesinde "ahlak ve iyiniyet kurallarına uymayan haller ve benzerleri" kapsamında haklı nedenle derhal fesih kapsamında hüküm tesis ettiği görülmektedir.

10 Anayasa Mahkemesi Serap Tortuk, $\$ \$ 32-36$; Ata Türkeri, B. No: 2013/6057, 16/12/2015, \$\$ 30, 32.

11 Anayasa Mahkemesi M.K, B. No: 2016/10325, 10/03/2021, $\$ \$ 32,34$.

12 Ece Ömüriş ve V. Rüya Ehtiyar, 'Örgütsel Yapılarda Romantik İlişkiler: Algılanan Güdüler ve Davranış Değişiklikleri Üzerine Bir Alan Araştırması' (2008) 16 Akdeniz İ.İ.B.F. Dergisi 21.

13 Yargıtay 9. HD, 33799/19760, 23.12.2020; Yargitay 9.HD, 9643/21252, 02.07.2007 (Sinerji Mevzuat ve İçtihat Bilgi Bankası). 
İş Kanunu md.18/f.1 belirsiz süreli iş sözleşmelerinin süreli olarak feshinde işverenin geçerli bir nedene dayanması gerektiğini öngörmüş ve bu nedenlerin neler olabileceğine ilişkin açıklık getirmiştir. Geçerli fesih sebepleri iş̧̧iye ilişkin nedenler olarak nitelendirilebilecek olan işçinin yetersizliğinden yahut davranışlarından kaynaklanan nedenlerden ile işletme gerekleri olarak özetlenebilecek işletmenin, işyerinin yahut işin gereklerinden kaynaklanabilir ${ }^{14}$. Bununla birlikte anılan düzenleme soyut bir nitelik taşımaktadır ve işçinin yeterliliği, davranışları yahut işletme gereklerinin hangi durumda geçerli sebeple feshe olanak sağlayacağı somut olayın özellikleri çerçevesinde hakim tarafından takdir edilerek belirginleştirilecektir ${ }^{15}$.

İşyerinde yaşanan duygusal ilişkiler İş Kanunu md.18/1 kapsamında işçinin davranışlarından kaynaklanan geçerli sebeple feshe konu olabilecektir ${ }^{16}$. Anılan maddenin gerekçesine göre 25 inci maddede belirtilen derhal fesih için öngörülen sebepler niteliğinde olmamakla birlikte, işçinin iş sözleşmesine aykııı davranışları bulunabilir. Bunlara örnek olarak, işverene zarar vermek ya da zararın tekrarı tedirginliğini yaratmak; işyerinde rahatsızlık yaratacak şekilde çalışma arkadaşlarından borç para istemek; arkadaşlarını işverene karşı kışkırtmak; işini uyarılara rağmen eksik, kötü veya yetersiz olarak yerine getirmek; işyerinde iş akışını ve iş ortamını olumsuz etkileyecek bir biçimde diğer kişilerle ilişkilere girmek; işin akışını durduracak şekilde uzun telefon görüşmeleri yapmak; sık sık işe geç gelmek ve işini aksatarak işyerinde dolaşmak; amirleri veya iş arkadaşları ile ciddi geçimsizlik göstermek, sıkça ve gereksiz yere tartışmaya girişmek gibi haller verilebilir ${ }^{17}$. Gerekçede yer verilen "işyerinde iş akışını ve iş ortamın olumsuz etkileyecek bir biçimde diğer kişilerle ilişkilere girmek" ifadesi muğlak bir nitelik taşımakla birlikte doktrinde işyerlerinde çalışan bekar işçiler veya evli işçiler arasında ortaya çıkabilecek duygusal ilişkiler yahut farklı cinsel tercihlere dayalı olarak yaşanabilecek ilişkilerin bazı koşullar altında bu kapsamda değerlendirilmesi mümkün görülmektedir ${ }^{18}$.

Gerekçede de belirtildiği üzere işçinin sosyal açıdan olumsuz bir davranışı, toplumsal ve etik açıdan onaylanmayacak bir tutumu işyerindeki üretim ve iş ilişkisi sürecine herhangi bir olumsuz etki yapmıyorsa geçerli sebep sayılamaz. Bu bağlamda işyerinde yaşanan duygusal ilişkinin işin normal yürütümünü, işyerindeki uyumu ve üretim sürecini aksatıp aksatmadığı her somut olayın özellikleri çerçevesinde hakim tarafından takdir edilecektir ${ }^{19}$. İşçinin davranışının taraflar arasında bulunması gereken güven temelini çökertecek biçimde ağır olmamakla birlikte işin normal işleyişini ve işyerindeki düzen ile uyumu bozması halinde işveren geçerli sebeple fesih hakkını kullanabilecektir ${ }^{20}$. Bununla birlikte iş̧̧inin işyerinde olumsuzluğa yol açan davranışı hakim tarafından ölçülülük denetimine tabi

14 Sarper Süzek, İş Hukuku (Yenilenmiş 19.Baskı Beta Yayıncılık 2020) 572; Nuri Çelik, Nurşen Caniklioğlu, Talat Canbolat ve Ercüment Özkaraca İş Hukuku Dersleri (Yenilenmiş 34.Baskı Beta Yayıncılık 2021) 530 vd.

15 Ali Güzel 'İşletmesel Kararların Keyfilik Denetimine Tabi Olması ve Geçerli Nedenle Fesihte Son Çare (Ultima Ratio) Olma İlkesinin Gözetilmesi (Karar İncelemesi)’ (2005) 1 Çalışma ve Toplum 163.

16 Ergin Gönül İlişkisi (n 3) s.70.

174857 Sayılı İş Kanunu ve Gerekçesi Türk-İş Ocak 201097.

18 Keser (n 5) 21.

19 Sarper Süzek, 'İşçinin Yetersizliği ve Davranışları Nedeniyle Geçerli Fesih’ Can Tuncay’a Armağan (Legal Yayıncılık 2005) 576

20 Yargitay 22.HD, 8393/22883, 10.12.2019; Yargitay 22.HD, 21515/20032, 24.10.2019 (Sinerji Mevzuat ve İçtihat Bilgi Bankasi) 
tutulacak olup amaç bu davranışın tekrar edilmesinin önüne geçmek olduğundan aynı amaca daha hafif önlemlerle erişilip erişilemeyeceği göz önünde tutulacaktır ${ }^{21}$.

İş sözleşmesini haklı nedene dayalı olarak derhal fesih hakkı ise dürüstlük kuralları çerçevesinde iş ilişkisini sürdürmesinin kendisinden beklenemeyecek olan tarafa sözleşmeyi derhal sona erdirme yetkisi veren bozucu yenilik doğuran bir hak olup taraflardan birinin davranışı yüzünden iş ilişkisinde bulunması gereken güven temeli çökmektedir ${ }^{22}$. İş Kanunu md.25/II bendine göre iş̧̧inin ahlak ve iyiniyet kurallarına uymayan davranışları haklı nedenle derhal fesih sebebi olmakla birlikte hangi durumların bu kapsamda değerlendirileceği konusunda sınırlayıcı bir sayıma gidilmediği görülmekte ve bendin kenar başlığında benzeri hallerin de haklı fesih nedeni olarak değerlendirileceği belirtilmektedir ${ }^{23}$. Yargıtay da ileride değinileceği üzere çeşitli tarihlerde verdiği kararlarda işyerinde yaşanan duygusal ilişkilerden bir kısmını haklı bir fesih sebebi olarak bu bent kapsamında değerlendirmekte ve her somut olayın özellikleri çerçevesinde değerlendirme yaparak hüküm tesis etmektedir. Bununla birlikte Yüksek Mahkeme’nin, ileride değinilecek olan kimi kararlarında bekar işçiler arasında yaşanan duygusal ilişkilere kıyasla evli işçiler arasındaki ilişkilere daha katı ve toleranssız bir biçimde yaklaştığı ve işyerinde olumsuz yansımaları olmasa dahi bu tür ilişkilerin çalışma düzenini bozduğu varsaydığı görülmektedir.

İşyerinde yaşanan duygusal ilişkilerde her iki tarafında rızası bulunmakta olup bu ilişkinin tarafları çalışanlar, çalışan yönetici yahut yöneticiler olabilmektedir ${ }^{24}$. Bu çerçevede kişilik haklarını ihlal eden, rahatsız edici bir çalışma ortamı yaratan, işyeri düzenini bozarak hapsi gerektiren suç yahut ahlak ve iyiniyet kurallarına aykırılık oluşturan, cinsel nitelikli davranışları içeren cinsel taciz ile karşılıklı rızaya dayanan duygusal ilişkileri ayırt etmek gerekmektedir ${ }^{25}$. Bir tarafın diğerini zorlayıcı nitelikte ve cinsel içerikli davranışları duygusal ilişki değil, cinsel taciz kapsamında değerlendirilecektir ${ }^{26}$. Bununla birlikte işyerinde bir çalışanın duygusal ve zorlayıcı olmayan şeklinde nitelendirdiği davranış diğer işçi tarafından cinsel taciz olarak algılanabileceği gibi sona eren duygusal ilişki

21 Deniz Ugan Çatalkaya, İş Hukukunda Ölçülülük İlkesi (1.Baskı Beta Yayıncılık 2019) 492.

22 Süzek İş Hukuku (n 14) 691; Çelik Caniklioğlu Canbolat ve Özkaraca (n 14) 628 vd. .

23 Süzek İş Hukuku (n 14) 694; Çelik Caniklioğlu Canbolat ve Özkaraca (n 14) 628, 630 .

24 Ergin Gönül İlişkisi (n 3) 70; Yiğit, (n 1) 3775.

25 Kadriye Bakırcı, İș Hukuku Açısından İşyerinde Cinsel Taciz (Birinci Baskı Yasa Yayınları 2000) 103 vd; Ergin Gönül İlişkisi (n 3) 70; Yiğit (n 1) 3776; Cinsel tacize ilişkin karşılaştırmalı hukuktaki düzenlemeler için bkz. Erdem Özdemir 'İşyerinde Cinsel Taciz', 2006 4, Çalışma ve Toplum 84 vd.

26 Daire 2019 yılında verdiği diğer kararında, davacının davalı işyerinde beraber çalıştığı ve yine davalı işyeri tarafından çalışanlar için ayarlanan otelde birlikte kaldığı, bekar kadın çalışan MB' ye karşı duygusal yakınlık duyduğu çalıştığı restoran haricinde başka bir restoranda ikisi için özel bir masa hazırlattığı ve kadın çalışanı buraya davet ettiği, restorana gelen kadın çalışanın masanın özel hazırlandığını, güllerle süslendiğini görünce oturmak istemediği ancak davacının bu hususta ısrarcı olduğu, kadın çalışanında oturmamakta ısrar etmesi üzerine konunun kapandığı, ertesi gün davacının kadın çalışanın yine bir restoranda başkası ile oturduğu masaya izin almadan oturduğu kadın çalışanın kalkmasını istemesi üzerine kalktığı, ancak bir müddet sonra geri gelip agresif davranışlar sergilediği masayı devirdiği bu durumun emniyet güçlerine haber verilmesi nedeniyle olay yerine polis geldiği ve durumun böylelikle adli bir boyutta kazandığ davacının iş akdinin bu eylem sebebiyle feshedildiği dosyadaki bilgi ve belgelerden anlaşıldığını ifade ettikten sonra olay işyeri dışında gerçekleşmiş ise de aynı işyerinde beraber çalıştığı ve aynı otelde beraber kaldığ bekar kadın çalışana karşı işlenmiş olması karşısında iş akdinin feshedilmemesi halinde mevcut olumsuzluğun doğrudan işyerine yansımasının kaçınılmaz olduğunu bu sebeple davalı işveren fesihte haklı değil ise de fesih geçerli nedene dayandığını ifade etmiştir. Yargitay 9.HD, 538/12543, 29.05.2019 (Sinerji Mevzuat ve İçtihat Bilgi Bankası). 
üzerine taraflardan birinin uzlaşma girişimleri de cinsel taciz olarak değerlendirilebileceğinden ayrım yapmak her zaman kolay olmamaktadır ve somut olayın özellikleri çerçevesinde nitelendirme yapmak uygun olacaktır ${ }^{27}$.

İşyerinde yaşanan duygusal ilişkilerin çalışma düzeninde yarattığı etkiler işverenin haklı yahut geçerli fesih hakkı bağlamında Yargıtay kararlarına konu olmakla birlikte Yüksek Mahkeme’nin bu konuda istikrarlı bir tutum izlememesi özellikle ileride değinilecek olan kararlarda görüldüğü üzere ahlaki bakımdan onay görmeyecek nitelikte ilişkileri işyerine olumsuz bir etkisi olmasa dahi haklı nedenle derhal fesih olanağı sağlayan sebepler arasında değerlendirmesi dikkat çekici niteliktedir. Anayasa Mahkemesi ise yukarıda sözünü ettiğimiz Esra Ünlü ile H.Ç başvurusunda verdiği kararlar ile işverenin fesih hakkına ilişkin kriterleri tespit etmiş ve AİHM uygulaması ile paralel bir tutum izleyerek bireylerin mahrem alanında kalan bu tür ilişkilerin özel hayatın gizli çerçevesi içerisinde kalacağını kabul etmiştir. Konuya ilişkin doktrinde de çeşitli görüşler ileri sürüldüğü görülmüş olduğundan işyerinde yaşanan duygusal ilişkilerin çalışma düzeni ve bu bağlamda işverenin fesih hakkına etkilerinin farklı yazarlar tarafından ileri sürülen görüşler, AYM kararı ile tespit edilen esaslar ve Yargıtay’n konuya ilişkin tutumu çerçevesinde incelenmesini gerekli kılmaktadır.

\section{B. DOKTRINDE ILERI SÜRÜLEN GÖRÜŞLER}

İşyerinde yaşanan duygusal ilişkilerin işyerinde yarattığı etkiler örgütsel psikoloji disiplini içerisinde gerek ulusal gerekse uluslararası literatürde farklı çalışmalara konu olmaktadır. Konunun iş hukukuna yansımasına bakıldığı vakit hangi durumlarda bireylerin mahrem alanı içerisinde kalan özel hayatına dahil olacağı ve hangi durumlarda işverene haklı yahut geçerli nedene dayalı olarak fesih hakkı vereceğinin diğer fesih sebeplerinden farklı olarak iş hukuku perspektifi ile yoğun bir biçimde tartışılmadığı görülmektedir. Genel olarak işyerine olumsuz yansıması olmayan bireylerin özel yaşamı içerisinde kalan duygusal ilişkilerin işverene fesih hakkı sağlamayacağı noktasında görüş birliği bulunmaktadır.

Doktrinde Ergin, işyerinde çalışan kişiler arasındaki gönül ilişkisinin özel yaşam sınırları içerisinde kaldığı ve çalışma ortamına olumsuz bir yansıması olmadığı sürece iş sözleşmesinin sona erdirilme nedeni olmamasını, bu tür bir ilişkiye müdahale etmenin özel yaşama müdahale olarak değerlendirilmesi gerektiğini ifade etmektedir ${ }^{28}$. Ayrıca yazara göre iş sözleşmelerine aynı işyerinde çalışan erkek ve kadın işçilerin evlenmesi durumunda ikisinden birinin işyerinden ayrılacağına yönelik konulan hükümlerin geçersiz olduğu kabul edilmelidir.

27 Yiğit (n 1) 3776; Bu yöndeki bir karar için bkz. "Davacının aynı işyerinde çalışan ... ile aralarında duygusal ilişki olduğu, evlenmeye karar verdikleri ancak ... vazgeçmesi üzerine davacının baskı yapmaya başladiğı, tehdit mesajları gönderdiğ $i$ ve en sonunda işyeri mutfă̆ında cinsel tacizde bulunduğu dosya içindeki bilgi ve belgelerden anlaşılmıştır. Ayrıca davacı bu eylemi nedeniyle ... . Ağır Ceza Mahkemesinde yargılanmış, suçu sabit görülmüş ancak hükmün açıklanmanın geri bırakılmasına karar verilmiştir... Davacının işyerinde çalışan arkadaşına karşı sabit olan eylemi nedeniyle iş akdinin feshi haklı nedene dayanmakla birlikte feshin yasal süresi içinde yapılmadiğı anlaşıldığından feshin geçerli hale geldiğ kabul edilerek davanın reddi gerekirken yazılı gerekçe ile kabulü hatalı olmuştur..." Yargıtay 7.HD, 23026/21586, 05.11.2015 (Sinerji Mevzuat ve İçtihat Bilgi Bankası) 
Sevimli işyerindeki cinsel tacizden işverenin sorumlu tutulabileceği gerekçesinin, çalışanlar arasında ilişki kurulmasının yasaklanmasını haklı kılmayacağını; aksinin kabulünün, işçinin özel yaşamına ağır şekilde müdahale sonucunu doğuracağını ifade etmektedir. Yazara göre işveren gönül ilişkilerini yasaklamak değil, işyerinde cinsel tacizi önlemeye ve sona erdirmeye yönelik, şikayet prosedürü başta olmak üzere etkili düzenlemeleri hayata geçirmekle yükümlüdür. İşyerindeki işçiler arasındaki gönül ilişkisi, işyerinin çıkarlarına zarar veren ya da görülen işi olumsuz etkileyen bir hal aldığında işveren için fesih hakkının doğumundan söz edilebilirse de; bu olasılık, daha baştan bu tür ilişkilerin, işi olumsuz etkileyeceği sonucuna varmayı haklı kılmaz ve işçinin özel yaşamına hukuka aykırı saldırı oluşturur 29 .

Keser işverene haklı yahut geçerli fesih hakkı verebilecek nitelikte işçi davranışının her somut olayda ayrıntılı olarak ele alınması ve incelenmesi, işverene, iş arkadaşlarına, müşterilere ve de en önemlisi iş ilişkisine olan etkilerinin değerlendirilmesinin gerekli olduğunu ifade etmektedir ${ }^{30}$. Yazara göre işverene haklı nedene derhal fesih yetkisi veren İş Kanunu md.25/II alt bendinin başlı̆̆ı her ne kadar ahlak ve iyi niyet kurallarına uymayan haller ve benzerleri olsa da, işçinin özel hayatı, aile hayatı ve cinsel yönelimlerinin maddede sayılan haller ile doğrudan ilişkilendirilebilmesi mümkün değildir. İşçinin meslek dışı, iş ilişkisini ilgilendirmeyen özel hayatına ilişkin davranışları, ifa ettiği görev ve işletmenin kendine özgü amacı çerçevesinde işyerinde "belirgin bir karışıklık, huzursuzluk veya sorun" yaratıyorsa bu durumda iş sözleşmenin geçerli sebeple feshedilebileceğinden söz edilebilecektir. İşyerinde yaşanan duygusal ilişkinin işyerinde belirgin şekilde bir soruna yol açtığının veya işveren ile olan güven ilişkilerini zedelediğinin objektif somut delillerle ortaya konulması gerekmektedir. İşyeri çalışanları arasındaki özel ilişkiler, işverence iş sözleşmesine konulan hükümlerle ya da sözlü/ yazılı talimatlarla yasaklanmış olsa dahi, bu tür bir yasaklama Türk Medeni Kanunu’nun 23 üncü maddesi de dikkate alındığında, özel hayata yani kişilik haklarına müdahale anlamına geleceğinden geçersiz kabul edilmelidir.

Yiğit de günümüz çalışma kuralları içerisinde işyerinde çalışanlar arasında romantik ilişkileri yasaklayan kurallar getirilmesinin güç ve bireysel hakları ihlal edici sonucu olduğunu, sırf duygusal ilişkinin varlığının AİHS ve Anayasa ile güvence altına alınan özel hayata karışmama ve saygı ilkesi gereği fesih konusu yapılamayacağını ifade etmektedir ${ }^{31}$. Duygusal ilişkinin işe, işyerine ve müşteri ilişkilerine zarar vermeye başlaması, işte meydana gelen aksamalar, evlilik dışı gönül ilişkileri, taciz ve sapkınlık boyutuna varan ilişkiler yahut işyerindeki duygusal ilişki kaynaklı uygunsuz hareket ve davranışlar ile olumsuzluklar haklı veya geçerli fesih sebebi olabilecektir. Yazar ayrıca işyerinde duygusal ilişkilere ilişkin yasaklamaların sözleşmelerle getirildiği hallerde bu düzenleme aykırı davranılması durumunda sırf duygusal ilişkiye dayalı olarak fesih işleminin geçerliliğinin kabul edilemez olacağını ifade etmektedir.

Civan da işçinin özel hayatını ilgilendiren gönül ilişkilerinin işyerinde somut olarak olumsuzluklara yol açmadığı sürece iş sözleşmesinin feshi açısından geçerli sebep oluşturmayacağını, işçiler arasında

29 Sevimli (n 2) 281, 282.

30 Keser (n 5) 16, 20, 21, 22, 26.

31 Yiğit (n 1) 3779, 3794. 
gönül ilişkisi olduğunu öğrenen işverenin yapması gerekenin işçinin özel hayatına saygı göstermek olduğunu ifade etmektedir ${ }^{32}$.

Yıldız da gönül ilişkisi yaşamanın tek başına iş sözleşmesinin işverence feshi bakımından gerekçe oluşturmayacağını, aynı işyerinde çalışan iki işçi arasındaki gönül ilişkisinin özel hayatın gizliliği kapsamında korunması gerektiğini bununla birlikte gönül ilişkisi devam ederken yahut sona erdikten sonra taraflardan biri yahut her ikisinin kusurlu davranışlarıyla işyerinde olumsuzluklara neden olması, iş sözleşmesinden doğan sadakat veya iş görme borcunu ihlal etmesi ve bu durumların işveren tarafından makul ölçüler içerisinde iş ilişkisine devam etmeyi beklenemez kılması durumunda ihlalin ağırlığına göre haklı yahut geçerli feshin gündeme gelebileceğini ifade etmektedir ${ }^{33}$.

Genel olarak yaşanan duygusal ilişkinin taraflarının aralarındaki sorunları işyerine yansıtmaları ve işlerini aksatmaları, yakınlarının işyerinde olay çıkarmaları, işyeri ortamında meydana gelen dedikoduların işverenin katlanmasının beklenemeyeceği düzeyde çalışma ortamının huzurunu bozması, duygusal ilişkiden hareketle işe geç gelinmesi gibi olumsuz durumlar duygusal ilişkinin işyerine olumsuz etkileri olarak kabul edilebilir ve bu takdirde işverenin geçerli nedenle fesih hakkı kabul edilebilir. Fakat iş sözleşmesinin duygusal ilişkinin işyerine olumsuz yansımaları sebebiyle geçerli sebeple feshinde de işveren eşit davranma yükümlülüğüne uygun davranmalı, ilişkinin taraflarının davranışının çalışma düzenini olumsuz etkilemesi durumunda her iki işçinin de sözleşmesinin feshi söz konusu olmalıdır ${ }^{34}$. Duygusal ilişki sebebiyle ortaya çıkan husumetlerin işçinin işverenin başka bir işçisine sataşması, ast-üst konumundaki çalışanlar arasında yaşanan ilişkiden cesaret alarak haklı feshe sebebiyet verecek biçimde devamsızlık yapılması yahut duygusal ilişki sebebiyle işçinin gözaltına alınması yahut tutuklanması ve bu sebeple devamsızlığın İş Kanunu md.17 çerçevesinde işçinin kıdemine göre belirlenen süreleri aşması gibi taraflar arasındaki güven temelini çökertecek düzeyde sonuçların ortaya çıktığı haller ise haklı fesih sebebi olarak değerlendirilebilecek niteliktedir. Bu ve benzeri şekilde güven temelini çökertecek düzeyde işyerine olumsuz yansıması bulunmayan duygusal ilişkilerin ise salt ahlaki kaygılarla doğrudan işverene haklı nedene derhal fesih yetkisi veren İş Kanunu md.25/II alt bendinde yer alan ahlak ve iyiniyet kurallarına uymayan haller ve benzerlerinin kapsamına alınması mümkün olmamalıdır. Nitekim Yargıtay’n ileride değinilecek olan kimi kararlarında toplumsal olarak kabul edilmeyen bir davranış söz konusu olsa bile işyerindeki duygusal ilişkilerin İş Kanununda sayılan haklı nedenle fesih gerekçeleri arasında bulunmadığını ifade ettiği görülmektedir ${ }^{35}$. Diğer bir deyimle duygusal ilişkinin işyerinde yarattığı olumsuzluğun iş ilişkisinde taraflar arasında bulunması gereken güven temelinin çökmesine sebep olup olmadığı her somut olayın özelliği çerçevesinde değerlendirilerek işverenin haklı yahut geçerli fesih hakkının doğup doğmadığı dikkate alınmalı; işyerine olumsuz yansıması

32 Orhan Ersun Civan, İşçinin Yan Yükümlülükleri (1.Baskı Beta Yayıncılık 2021) 184.

33 Gaye Burcu Yıldız 'İşyerinde Yaşanan Gönül İlişkisinin İş Sözleşmesinin İşverence Feshi Açısından Değerlendirilmesi' (2021) 3 (XXV) Ankara Hacı Bayram Veli Üniversitesi Hukuk Fakültesi Dergisi 35.

34 Keser (n 5) 26; Yiğit (n 1) 3783; İşyerinde çalışan diğer işçilerin gönül ilişkisinden rahatsılılı duymasının tek başına fesih için geçerli yahut haklı sebep oluşturmayacağı yönündeki görüş için bkz. Yıldız (n 33) 15.

35 Yargitay 22. HD, 17221/22711, 24.10.2017; Yargitay 22.HD, 17587/22860, 01.07.2015 (Sinerji Mevzuat ve İçtihat Bilgi Bankası). 
bulunmayan ilişkilerin ise bireylerin mahrem alanında kaldığı kabul edilerek özel hayatın gizliliği kapsamında değerlendirilme yapılmalıdır.

\section{ANAYASA MAHKEMESI'NIN 30/09/2020 TARIHLI KARARI}

Anayasa Mahkemesi yeni tarihli bir kararı ile (30/09/2020 tarihli 2017/14907 başvuru no.lu) ${ }^{36}$ aynı işyerinde çalışan kişilerin ilişkiye girmelerinin işverenin fesih hakkı üzerindeki etkisini inceleme konusu yapmıştır. Özel hayata saygı kavramının AİHM kararları çerçevesinde ayrıntılı bir biçimde incelendiği karar aşağıda çeşitli açılardan ele alınmaya çalışılacaktır.

\section{I.KARARA KONU OLAN OLAY VE MERCILERIN ÇÖZÜM TARZI}

Başvurucu özel bir şirkette çalışmaktadır ve başvurucunun çalıştığı özel şirketi telefonla arayan bir kişi "Başvurucunun terör örgütü mensubu olduğu, bombalı eylemde bulunacağı ve işyeri sahibine yönelik işyerinde sabotajda bulunacağı" şeklinde ihbarda bulunmuştur. İşveren ise başvurucunun V.B. isimli şirket çalışanı ile ilişkisinin olduğu, bu ilişkiyi öğrenen V.B.nin eşinin şirket çağrı merkezini arayarak başvurucunun canlı bomba olduğuna dair ihbarda bulunduğunun yapilan iç araştırma ve V.B.nin savunmasından anlaşıldığını belirtmiştir. Yapılan ihbar nedeniyle İlçe Emniyet Müdürünün şirkette inceleme yaptığı, üretim kaybı, korku gibi huzursuzluk yaratan durumların meydana geldiği ifade edildikten sonra anılan olayın oluşumunda başvurucunun işyerinde başka bir çalışan ile yaşadığ ilişkinin etkili olduğu vurgulanarak İş Kanunu’nun 25. maddesinin (II) numaralı bendi uyarınca iş sözleşmesi feshedilmiştir. Başvurucu tarafından açılan dava üzerine iş mahkemesi başvurucunun diğer çalışan ile çalışma alanında ya da işyerinde iş ilişkisi dışında farklı bir ilişkilerinin olduğuna dair delilin ortaya konulamadığı gerekçesi ile fesih kararının yerinde olmadığını ve feshin son çare olması ilkesinin gözetilmediğini ifade etmiştir. Kararın temyizi üzerine Yargıtay 22. Hukuk Dairesi, davacı ile ilişki yaşadığı iddia edilen işçinin savunması dikkate alındığında, başvurucunun çalışma arkadaşlığı ilişkisini aşan bir ilişki yaşadığı, bu ilişkinin işyerinde olumsuzluklara yol açtığının anlaşıldığını; haklı fesih sebebi ağırlığında olmasa da işin yürütümünü bozucu nitelikte olduğu, işyerinde olumsuzluğa yol açtı̆̆ 1 ve iş ilişkisinin sürdürülmesinin, işveren açısından beklenemeyeceğini vurgulayarak iş sözleşmesinin feshinin geçerli sebebe dayandığının kabulü gerektiği sonucuna ulaşmıştır.

$\mathrm{Bu}$ olay çerçevesinde irdelenmesi gereken temel hukuki sorun işyerinde yaşanan duygusal ilişkilerin hangi durumlarda işverene haklı yahut geçerli nedenle fesih hakkı vereceği, ispat araçlarının neler olduğu ve özel yaşama saygı sınırları içerisinde kalacak durumların ne şekilde tespit edileceğidir. Anayasa Mahkemesi işyerinde kurulan duygusal ilişkiler bağlamında özel hayata saygı hakkının korunmasına ilişkin yaklaşımları geliştirirken işverenin haklı ve geçerli nedenle fesih hakkına ilişkin iç hukuk mevzuatına atıf yaptıktan sonra AİHM kararlarına da yer vermiş ve uluslararası hukuku da göz önünde tutmuştur.

36 Anayasa Mahkemesi H.Ç, B. No: 2014/14907, 30/09/2020, Resmi Gazete: 9.12.2020 S.31329 https://kararlarbilgibankasi. anayasa.gov.tr/BB/2017/14907 Erişim:8 Mayıs 2021 


\section{ANAYASA MAHKEMESI'NIN YAKLAŞIMI}

Anayasa Mahkemesi, kararına esas teşkil eden hukuki kaynak ve referanslara geniş bir biçimde yer vermiştir. Mahkemenin gönderme yaptığı ilk iç hukuk düzenlemesi iş sözleşmesinin haklı nedenle derhal feshine ilişkin 25.maddenin "Ahlak ve iyiniyet kurallarına uymayan haller ve benzerleri” kenar başlıklı II.bendi, geçerli sebeple feshi düzenleyen 18.Madde ve sözleşmenin feshine ilişkin usulü düzenleyen 19. Madde olarak karşımıza çıkmaktadır. İleride Yargıtay’ın konuya ilişkin yaklaşımı bahsinde ele alınacağı üzere haklı sebep iş sözleşmesinin bildirim öneli vermeye gerek olmaksızın derhal feshedilmesini sağlamakta, bir tarafı dürüstlük kuralı çerçevesinde sözleşme ile bağlı kalmaktan kurtarmaktadır. Geçerli sebepler ise haklı fesih sebebinden farklı olarak iş ilişkisini derhal sona erdirme hakkı vermemekte, hukuki bakımdan dürüstlük kuralı çerçevesinde sözleşmenin devamını çekilmez hale getirmemekte, yalnızca işyerini olumsuz bir biçimde etkileyici bir görünüm arz etmektedir.

Anayasa Mahkemesi kararlarını belirleyici referans norm olarak Avrupa İnsan Hakları Sözleşmesi ve bu sözleşmede yer alan hakları somutlaştıran Avrupa İnsan Hakları Mahkemesi içtihadı anılan karar bakımından da önemli bir kaynak olarak karşımıza çıkmaktadır. Kararda atıf yapılan Denisov/ Ukrayna (B. No: 76639/11, 25/10/2018) kararı iş uyuşmazlıkları bağlamında özel hayat kavramına ilişkin temel ilkeleri ortaya koymaktadır. Kararda mesleki hayatın bazı durumlarda özel hayat alanına girebileceği, kişiler ve başkaları arasındaki etkileşim alanının bir parçasını teşkil edebileceği hatırlatıldıktan sonra bu tür davalarda özel hayat kavramının iki farklı yaklaşıma göre uygulanabileceği açıklanmıştır. AİHM bu kapsamda; sebebe dayalı yaklaşım olarak nitelendirdiği birinci yaklaşım şeklinde, uyuşmazlık nedeninin özel hayata ilişkin bir unsura dayanıp dayanmadığını irdelemiştir. İkinci yaklaşım şekli ise AİHM tarafından sonuca dayalı yaklaşım olarak belirlenmiş ve itiraz edilen tedbirin sonuçları bakımından özel hayata dokunan bir yönünün olup olmadığı sorgulanmıştır. Yine gönderme yapılan Özpınar/Türkiye (B. No: 20999/04, 19/10/2010) ve Niemietz/Almanya (B. No: 13710/88, 16/12/1992) kararlarında, özel yaşam kavramını tanımlamanın gereksiz ve imkansız olduğunu belirten AİHM, takip eden pek çok farklı kararında da, kavramın çok geniş olduğunu ve açıkça tanımlanamayacağını ifade etmiştir ${ }^{37}$. Bu kararlara göre insanların büyük çoğunluğu, dış dünya ile olan ilişkilerini geliştirme olanaklarını en çok mesleki hayatları çerçevesinde yürüttükleri faaliyet kapsamında elde ettiğinden mesleki hayat özel hayat kavramı dışında tutulamaz. Özel hayat unsurları gerekçe gösterilerek mesleki hayata getirilen sınırlamalar, bireyin sosyal kimliğini etkilediği ölçüde Sözleşme’nin 8. maddesi kapsamına girebilmektedir.

Anayasa Mahkemesi, "Herkes, özel hayatına ve aile hayatına saygı gösterilmesini isteme hakkına sahiptir. Özel hayatın ve aile hayatının gizliliğine dokunulamaz" hükmünü içeren "özel hayatın gizliliği” kenar başlıklı Anayasa’nın 20. maddesi çerçevesinde başvurunun kabul edilebilir olduğunu ifade ederek incelemeye başlamıştır. Özel hayata saygı hakkı Anayasa’nın 20. maddesinde koruma altına alınmıştır. Devlet, kişilerin özel ve aile hayatına keyfî olarak müdahale etmemek ve üçüncü

37 Anılan kararlar için bkz. P.G. and J.H. v. UK, Appl. No. 44787/98, judgment of 25/09/200; K.A. and A.D. v. Belgium, Appl. No. 42758/98, 45558/99, judgment of 17/02/2005; S. and Marper v. UK, Appl. No. 30562/04 ve 30566/04, judgment of 04/12/2008. 
kişilerin haksız saldırılarını önlemekle yükümlüdür. Özel hayat geniş bir kavram olup bu kavramın kapsayıcı bir tanımının yapılması oldukça zordur. Bununla beraber bu kavram; kişinin maddi ve manevi bütünlüğü, fiziksel ve sosyal kimliği, bireyin ismi, cinsel yönelimi, cinsel yaşamı gibi unsurları korumaktadır. Kişisel bilgiler ve veriler, kişisel gelişim, aile hayatı vb. konular da bu hakkın içinde yer almaktadır. Kişinin mesleki hayatı da bu kapsamda değerlendirilebileceğinden iddia kabul edilebilir nitelikte görülmüştür (par 33)

Esas bakımından ise Mahkeme meseleyi devletin, özel hayata saygı hakkını etkili olarak koruma ve saygı gösterme şeklinde pozitif yükümlülüğü bulunduğundan hareketle ele almıştır. Bu yükümlülük bireylerin birbirlerine karşı eylemleri bakımından anılan hakkın korunması için gerekli önlemlerin alınmasını da içerir (par 36). Kamu gücünü kullanan aktörler dışında kalan kişiler arasındaki özel hukuk ilişkilerinde kamusal makamların yükümlülükleri; bireylerin temel hak ve özgürlüklerine üçüncü kişilerin müdahalesinin önlenmesi için gerekli önlemlerin alınması ve mahkemelerce korunma sağlanmasıdır. Kamusal makamlarca gerekli yapısal önlemler alınmış olunsa da uyuşmazlık konusu davayı yürüten mahkemelerce verilen kararlarda üçüncü kişilerin müdahalelerine karşı bireylere korunma imkânı sağlanmadığ 1 durumlarda bu yükümlülükler gereği gibi yerine getirilmemiş olacaktır (par 38). Bu doğrultuda, özel hukuk iş ilişkisi kapsamında çalışan bireylerin Anayasa ile güvence altına alınan haklarına yönelik müdahale iddiası içeren uyuşmazlıklarının karara bağlandığı davalarda derece mahkemelerince söz konusu güvenceler gözardı edilmemeli, işveren ve çalışanlar arasındaki çatışan çıkarlar adil biçimde dengelenmeli, müdahalenin işverenin meşru amacıyla ölçülü olup olmadığı değerlendirilmeli ve ulaşılan sonuç hakkında hüküm kurulurken ilgili ve yeterli gerekçeler sunulmalıdır (par 39).

Anayasa Mahkemesi, somut olaydaki uyuşmazlı̆̆ın özel hukuk kişileri arasında gerçekleşmesi nedeniyle temel hak ve özgürlüklerin sağladığı güvencelerin yerine getirilmediği iddiasını içeren başvurunun devletin pozitif yükümlülükleri bağlamında ele alınması gerektiğini ifade ederek çeşitli ilkeler geliştirmiştir. Buna göre işlerin etkin bir şekilde yürütülmesi, iş sağlığı ve güvenliği gibi haklı ve meşru görülebilecek nedenlerle işverenin, kural olarak çalışanın özel hayatı kapsamında kalan bazı davranış ve eylemlerine ilişkin sınırlamalar getirebileceği söylenebilir. İşçinin aynı işyerinde çalışan başka bir işçiyle ilişki yaşaması hâlinde işverenin sadece bu nedene dayanarak iş sözleşmesini feshedebileceğini kabul etmek, işçinin demokratik bir toplumda temel haklarına ve özgürlüklerine işyerinde de saygı gösterilmesi gerektiği yönündeki haklı beklentisiyle uyuşmayacağından çalışanın diğer bir çalışanla yaşadığı ilişkinin işin yürütülmesini, iş sağlığını ve güvenliğini etkileyip etkilemediği önem taşımaktadır (par 42). Devletin pozitif yükümlülüğüne ilişkin ilkelerle birlikte değerlendirildiğinde, iki çalışan arasındaki ilişkinin iş sözleşmesinin feshi nedeni olarak kabul edilebilmesi için ilişkinin varllğ̆ ve anılan ilişkinin işin yürütülmesine olumsuz etkileri ile birlikte iş sözleşmesinin sürdürülmesinin işveren açısından beklenemeyeceğinin işveren tarafından tam olarak ortaya konulması gerektiği sonucuna ulaşılmıştır. Ayrıca derece mahkemeleri tarafından da ilişkinin işyerine ve işin işleyişine olan yansımaları işyerinin kapasitesi, iş̧̧inin ifa ettiği görevi, sicili, ilişkinin kim tarafından alenileştirildiği gibi hususlar gözetilerek değerlendirilip yeterli ve ilgili gerekçe ile açıklanmalı, iş sözleşmesinin feshinin işverenin meşru amacına uygun ve orantılı olup olmadığ 1 gözetilerek işveren ile çalışan arasındaki çatışan çıkarlar adil biçimde dengelenmelidir (par 43). 
Anılan bu prensipleri somut olaya uygulayan Mahkeme şu sonuçlara ulaşmıştır: İşveren iş sözleşmesini, başvurucunun V.B. isimli işçi ile ilişkisi olduğu, bu ilişki nedeniyle V.B.nin eşinin yaptığ bir ihbar sonucu zarara uğradığı gerekçesiyle feshetmekle birlikte ceza soruşturması kapsamında ihbarı yapan kişinin V.B.nin eşi olmadığı ve ihbarın var olduğu iddia edilen ilişki ile ilgisinin bulunmadığı ortaya çıkmıştır. Ayrıca yargılama sürecinde işverenin anılan ihbar nedeniyle şirkete polisin gelerek inceleme yaptığı, işin durduğu ve bu nedenle zarara uğradığına yönelik iddialarını destekleyen belge sunamadığı, Mahkeme’nin bu konuda ayrıca bir araştırma yapmadığı ve dinlenen tanıkların işyerinde anılan olumsuzluklara yönelik beyanlarının alınmadığı görülmüştür. Öte yandan üretime ara verilmiş ve işveren zarara uğramış olsa bile bu durumun başvurucunun kusurundan kaynaklanmadığının sabit olduğu dikkate alındığında, başvurucunun yaşadığı iddia edilen ilişkinin işyerinde olumsuzluklara neden olduğu hususunun işveren tarafından ortaya konulamadığı anlaşılmaktadır (par 44). Olayda işverenin, V.B.nin savunmasını almasına ve yargılama aşamasında bu savunmayı delil olarak mahkemeye sunmasına rağmen, iddia edilen ilişkinin tarafı olan başvurucunun savunması alınmayarak ilişkinin varlığına ilişkin tek taraflı bir beyana dayanıldığı ve yargılama aşamasına kadar başvurucuya bu beyana karşı görüşlerini sunma imkânının işveren tarafından tanınmadığı hususlarının gözetilmediği; derece mahkemesi tarafından da iddialar karşısında V.B.nin tanık olarak dinlenmediği, işveren tarafından dosyaya sunulan savunmasının doğruluğunun araştırılmadığı görülmüştür (par 45). Tüm bu hususlar birlikte değerlendirildiğinde başvurucunun başka bir işçiyle ilişskisinin olduğu, bu ilişkinin başvurucu tarafından alenileştirildiği ve ilişkinin işyerine olumsuz etkilerinin olduğu, ayrıca oluşan olumsuzluklar nedeniyle iş sözleşmesinin sürdürülmesinin işverenden beklenemeyeceği hususlarının işveren tarafından ortaya konulamadığı; iddia edilen ilişkinin varlığına ve işyerine yansımalarına ilişkin yeterli bir araştırmanın yapıldığı ve olaya özgü gerekçe sunulduğunun söylenemeyeceği; iş sözleşmesinin feshinin işverenin amacına uygun ve orantılı olup olmadığı hususu gözetilerek işveren ile çalışanın çıkarları arasında adil bir denge kuracak özenli bir yargılama yapılmadı̆̆ı sonucuna varılmıştır (par 46).

Son tahlilde Mahkeme, Anayasa’nın 20. maddesinde güvence altına alınan özel hayata saygı hakkının oybirliği ile ihlal edildiğine, kararın bir örneğinin sonuçlarının ortadan kaldırılması için yeniden yargılama yapılmak üzere Manisa 1. İş Mahkemesi’ne gönderilmesine, ihlalin ve sonuçlarının ortadan kaldırılması için yeniden yargılamanın yeterli bir giderim sağlayacağı anlaşıldığından tazminat talebinin reddine karar verilmesi gerektiği sonucuna ulaşmıştır.

İlginç olan husus, 22. Hukuk Dairesi’nin henüz Anayasa Mahkemesinin bu kararı yayınlanmadan önce 11.11.2019 tarihinde bu sefer muhtemelen aynı işçinin kıdem-ihbar tazminatı talepli davasını da karara bağlamış olmasıdır. Yüksek Mahkeme, Anayasa Mahkemesi tarafından Anayasa’ya aykırı bulunan içtihadını bu kararında da sürdürmüş, evli bir iş arkadaşı ile ilişkiye giren ve kendisi de evli olan davacının iş sözleşmesinin feshini aşağıdaki gerekçeler ile geçerli kabul etmiştir: "Öncelikle dava dışı ... isimli bayanın davacı veya davacının eşi ile ilgisi olup olmadığı hususu net olmadığı gibi davacının eşi tarafından canlı bomba ihbarının yaptırıldığı varsayımında dahi üçüncü kişi tarafından yapılan bu eylem davacının iş akdinin feshi için haklı fesih sebebi olmayacaktır. Ancak dosya kapsamında bulunan tutanaklar dikkate alındığında davacı ile işyerinde çalışan bayan işçi arasında ilişki olduğu sabittir. Davacının evli olması da dikkate alındığında bu tür bir ilişki toplumsal olarak kabul edilmeyen bir 
davranış olsa bile iş sözleşmesinin feshi noktasında İş Kanununda sayılan haklı nedenle fesih gerekçeleri arasında bulunmamaktadır. İşverenin bu davranışı yapan davacı işçi ile iş ilişkisini sürdürmesi beklenemeyeceğinden, işverence yapılan feshin geçerli sebebe dayandığı kabul edilmelidir"38. Bu şekilde Yüksek Mahkeme en azından feshin haklı nedene dayandığı ve işçinin kıdem-ihbar tazminatına da kazanmayacağı yönündeki yerel mahkeme kararını bozmuştur.

\section{D.ANAYASA MAHKEMESI'NIN 25/2/202I TARIHLI KARARI}

Anayasa Mahkemesi 2020 yılında H.Ç başvurusunda verdiği kararda oluşturduğu esasları uygulamak suretiyle işyerinde yaşanan duygusal ilişkilere ilişkin olarak 25/2/2021 tarihli Esra Ünlü başvurusunda da (25/2/2021 tarihli 2018/1444 başvuru no.lu) $)^{39}$ işyerinde yaşanan duygusal ilişkileri özel hayata saygı hakkı kapsamında incelemiştir. H.Ç başvurusunda verilen kararda tespit edilen özel hayata saygı hakkı ve işyerinde yaşanan duygusal ilişkilerin işverenin fesih hakkına etkisine ilişkin esaslar kararda da tekrarlanmış olduğundan burada yalnızca karara esas teşkil eden somut olaya ve mercilerin çözüm tarzına yönelik açıklamalara yer verilecek, buna karşılık tekrar eden hususlarla ilgili esaslara somut olay ile bağlantılı olduğu ölçüde değinilecektir.

\section{I.KARARA KONU OLAN OLAY VE MERCILERIN ÇÖZÜM TARZI}

Başvurucu özel bir şirkette mağaza sorumlusu olarak çalışmaktadır. Başvurucunun aynı şirkette çalışan M.E’nin telefonuna gönderdiği mesaj M.E’nin telefonuna yüklenen bir uygulama sebebiyle şirketin e-posta hesabına yansımıştır. Mesajların incelenmesi sonucu başvurucunun iş sözleşmesi işveren tarafından başvurucunun çalışma arkadaşı ile iş ahlak ve etiğine aykırı şekilde ilişkisi olduğu tespit edilerek savunması alınmak suretiyle İş Kanunu’nun 25. maddesinin (II) No.lu bendi uyarınca haklı nedenle derhal feshedilmiştir. Başvurucu feshe karşı iş mahkemesinde işe iade istemi ile tespit davası açmıştır. Mahkeme yargılama süresinde başvurucunun da bildirmiş olduğu tanıkları dinlemiş ve M.E ile başvurucu arasındaki mesajların özel hayata saygı hakkı kapsamında kaldığını, hukuka aykırı elde edilmiş delillerin olayın ispatında dikkate alınamayacağını, tanık anlatımlarından da herhangi bir uygunsuz davranışın görülmediğini, ilişkinin işe yansımadığının anlaşıldığını ifade ederek feshin geçersizliğine ve işçinin işe iadesine karar vermiştir. Dava konusu olayda ilk derece mahkemesi tarafından yapılan yargılama esnasında tanık olarak dinlenen M.Ẻnin duygusal ilişkinin işten çıkarılmadan birkaç ay önce bittiğini ancak bu ilişkinin işyerine olumsuz yansımalarının olmadığını, ayrıca bölge sorumlusu olarak dokuz mağazanın kontrollerini yaptığını, bu kapsamda başvurucunun çalsştı̆̆ mağazaya da haftada iki üç kez gittiğini ve toplam dört saat mağazada kaldığını, işverenin asıl amacının kendisini işten çıkarmak olduğunu, gönül ilişkisini bahane ederek ikisinin de iş sözleşmesini sonlandırdığını beyan etmesi dikkat çekici niteliktedir. İşverenin istinaf başvurusu üzerine Bölge Adliye Mahkemesi, başvurucunun üstü konumundaki bölge sorumlusu

38 Yargıtay 22. HD, 23324/20727, 11.11.2019 (Sinerji Mevzuat ve İçtihat Bilgi Bankası).

39 Anayasa Mahkemesi Esra Ünlü B. No: 2018/1444, 25/2/2021, https://kararlarbilgibankasi.anayasa.gov.tr/BB/2018/4144 Erişim: 31 May 2021. 
çalışan ile duygusal ilişki yaşadığının, başvurucunun M.E.nin telefonuna gönderdiği mesajların iradeleri dışında olsa da şirketin mail programına geldiğinin anlaşıldığını ifade etmiştir. Mahkemeye göre başvurucunun evli olan ve üstü konumundaki diğer çalışanla bitmiş bile olsa ilişki yaşaması davalı işverende olumsuzluğa yol açacak, iş barışı ve huzurunu bozacak, işveren işçiye güvenini yitirecek ve davalı işveren yönünden iş ilişkisinin sürdürülmesini çekilmez hâle getirecek niteliktedir; bu itibarla işveren açısından fesih tarihi itibari ile geçerli nedenlerin bulunduğu anlaşılmaktadır. Ayrıca tarafların ilişkisinin diğer çalışanlarca bilinmediği, iş ortamına yansıtılmadığı, işe olumsuz etkisi olmadığ 1 yönündeki beyanlara da itibar edilemediği kararda belirtilmiştir. Başvurucu ile ilişkisi olduğu iddia edilen M.E’nin iş sözleşmesinin işveren tarafından feshi üzerine açılan işe iade davasının da ilk derece mahkemesi tarafından reddedildiği ancak bu kararın da Bölge Adliye Mahkemesi tarafından fesih nedeni olarak gösterilen ilişkinin fesih tarihinden birkaç ay önce sona erdiği ve bu ilişkinin işyerinde bir olumsuzluğa sebep olmadığının anlaşıldığı belirtilerek kaldırıldığı görülmektedir. Davacı M.E.nin başvurucu ile ilişkisinin olduğunu kabul ettiği, bu şekilde evli olan davacının astı konumundaki iş arkadaşıyla özel ilişki yaşadığının sabit olduğu, davacının davranışlarının işyerinde olumsuzluklara neden olduğu, işverenden iş ilişkisini sürdürmesinin beklenemeyeceği, iş sözleşmesinin feshinin geçerli nedenlerinin olduğu değerlendirilmesine yer vermek suretiyle Bölge Adliye Mahkemesi ve İlk Derece Mahkemesinin kararları Yargıtay 22.Hukuk Dairesi tarafından 7/3/2018 tarihinde bozulmuştur ${ }^{40}$.

\section{ANAYASA MAHKEMESI'NIN YAKLAŞIMI}

Anayasa Mahkemesi, 2020 yılında H.Ç başvurusu kararına esas teşkil eden hukuki kaynak ve referanslara Esra Ünlü başvurusunda da yer vermiş; iç hukukta iş sözleşmesinin haklı nedenle derhal feshine ilişkin 25. maddenin "Ahlak ve iyiniyet kurallarına uymayan haller ve benzerleri" kenar başlıklı II.bendi, geçerli sebeple feshi düzenleyen 18.madde ve sözleşmenin feshine ilişkin usulü düzenleyen 19. maddeye atıf yaparak incelemeye başlamıştır. Mahkeme’nin H.Ç başvurusuna benzer bir biçimde AİHM'in özel hayat kavramının kapsamını tayin ettiği Denisov/Ukrayna (B. No: 76639/11, 25/10/2018), Niemietz/Almanya, (B. No: 13710/88, 16/12/1992) ve Özpinar/Türkiye (B. No: 20999/04, 19/10/2010) kararlarına atıf yaptığı ve AİHM yargıcının belirlediği esasları göz önünde tutmaya çalıştı̆̆ bu kararda da görülmektedir.

Mahkeme, "Herkes, özel hayatına ve aile hayatına saygı gösterilmesini isteme hakkına sahiptir. Özel hayatın ve aile hayatının gizliliğine dokunulamaz" hükmünü içeren "özel hayatın gizliliği” kenar başlıklı Anayasảnın 20. maddesi çerçevesinde başvurunun kabul edilebilir olduğunu ifade ederek incelemeye başlamıştır. Yüksek mahkemeye göre işlerin etkin bir şekilde yürütülmesi, işs sağllğı ve güvenliği gibi haklı ve meşru görülebilecek nedenlerle işverenin, kural olarak çalışanın özel hayatı kapsamında kalan bazı davranış ve eylemlerine ilişkin sınırlamalar getirebileceği söylenebilir. Bununla birlikte işverenin yetki ve haklarının sınırsız değildir ve çalışana tanınan temel hak ve özgürlükler - somut olayda özel hayata saygı hakkı - işyeri sınırları dahilinde de korunmaktadır; kısıtlayıcı ve uyulması zorunlu işyeri kuralları çalışanların temel haklarının özünü zedeleyecek 
nitelikte olmamalıdır. İşçinin aynı işyerinde çalışan başka bir işçiyle ilişki yaşaması hâlinde işverenin sadece bu nedene dayanarak iş sözleşmesini feshedebileceğini kabul etmek, işçinin demokratik bir toplumda temel haklarına ve özgürlüklerine işyerinde de saygı gösterilmesi gerektiği yönündeki haklı beklentisiyle uyuşmayacaktır. Bu çerçevede çalışanın diğer bir çalışanla yaşadığı ilişkinin işin yürütülmesini, iş sağlığını ve güvenliğini etkileyip etkilemediği önem taşımaktadır (par 40).

H.Ç başvurusunda tespit ettiği esasları yineleyen ve iki çalışan arasındaki ilişkinin iş sözleşmesini fesih nedeni olarak kabul edilebilmesi için ilişkinin varlığı ve anılan ilişkinin işin yürütülmesine olumsuz etkileri ile birlikte iş sözleşmesinin sürdürülmesinin işveren açısından beklenemeyeceğinin işveren tarafından tam olarak ortaya konulması gerektiği sonucuna ulaşan Mahkeme (par 41), işverenin başvurucu ile evli ve çalışma üstü olan M.E arasında yaşanan ilişsinin işyerinde nasıl ve ne gibi olumsuzluklara neden olduğu konusunda somut bir bilgi sunamadığı sonucuna ulaşmıştır (par 42). Mahkemeye göre yargılama süreci bir bütün olarak değerlendirildiğinde başvurucu ile M.E. arasında fesih tarihinden önce bitmiş bir ilişkinin olduğu, bu ilişkinin başvurucu ve M.E tarafından alenileştirilmediği, tanık anlatımlarına göre iş sözleşmesinin feshi ile alenileşen ilişkinin diğer işçiler tarafından ve işveren tarafından bilinmediği, bu durumun işyerinde bir olumsuzluğa sebep olmadığı hususlarının sabit olduğu söylenebilecektir (par 42). Özel hukuk iş ilişkilerinden doğan uyuşmazlıkları karara bağlayan derece mahkemelerince özel hayata saygı hakkına ilişkin Anayasa'da belirtilen güvencelerin gözetildiği özenli bir yargılama yapılmadığı, dolayısıyla anayasal güvencelerin korunması açısından pozitif yükümlülüklerin yerine getirilmediği anlaşıldığından başvurucunun Anayasa’nın 20. maddesinde güvence altına alınan özel hayata saygı hakkının ihlal edildiğine karar verilmesi gerektiği sonucuna ulaşılmıştır (par 44).

Son tahlilde Mahkeme oybirliği ile Anayasa’nın 20. maddesinde güvence altına alınan özel hayata saygı hakkının ihlal edildiğine, kararın bir örneğinin sonuçlarının ortadan kaldırılması için yeniden yargılama yapılmak üzere Karaman İş Mahkemesi’ne gönderilmesine, ihlalin ve sonuçlarının ortadan kaldırılması için yeniden yargılamanın yeterli bir giderim sağlayacağı anlaşıldı̆̆ından tazminat talebinin reddine karar verilmesi gerektiği sonucuna ulaşmıştır.

\section{E. YARGITAY'IN YAKLAŞIMI}

\section{GENEL OLARAK}

İşyerinde yaşanan duygusal ilişkilerin işyerine olumsuz yansımaları ilişki sebebiyle çalışma ortamının huzurunu bozacak düzeyde dedikoduların ortaya çıkması, özellikle ast-üst konumdaki çalışanlar arasındaki ilişkiye bağlı olarak kayırmacılık ve ilişkinin verdiği rahatlığa dayanarak işin görülmesinde özensizliklerin baş göstermesi, ilişki sırasında taraflar arasında ortaya çıkan tartışmaların işyerine yansıması, ilişkinin taraflarının eşleri yahut yakınlarının işyerine sirayet eden davranışları ve müdahaleleri sebebiyle çalışma düzeninin etkilenmesi gibi farklı şekillerde karşımıza çıkabilmektedir. Bu olumsuz etkilerin bir katalog halinde sınırlı bir biçimde sıralanması mümkün olmamakla birlikte Yargıtay'ın farklı tarihlerde verdiği ve ortak özelliklere sahip olan kararlar olduğu görülmektedir. Aşağıda görüleceği üzere Yüksek Mahkeme’nin kimi kararlarında 
AYM ile paralel esasları takip ederek duygusal ilişkinin işe, işyerine yahut çalışma düzenine olumsuz etkilerinin yeterli delil ve gerekçelerle ortaya konulmasını ararken, kimi kararlarında taraflar arasındaki ilişkinin işyerinde olumsuzluk yarattığına dair varsayımdan hareketle hüküm tesis ettiği görülmektedir ${ }^{41}$. Anılan olumsuz etkiler Yargıtay'ın geliştirdiği yaklaşımlar çerçevesinde ele alınarak Yüksek Mahkeme’nin verdiği kararlar ile Anayasa Mahkemesi’nin H.Ç ve Esra Ünlü kararında ortaya koyduğu esasların ayrıştığı noktalar tespit edilmeye çalışılacaktır.

\section{HIYERARŞIK ILIŞKI iÇERISINDE BULUNAN ÇALIŞANLAR ARASINDAKI DUYGUSAL iLIŞKININ IŞ ILIŞKISINE ETKILERI}

Hiyerarşik ilişki içindeki çalışanların duygusal ilişkileri, işyerinde kayırmacılık tehlikesini doğurmaya elverişlidir. Kayırmacılık, çalışanlara yapılan muamelede yakın ilişki ağlarını̈ ön plana çıkarıp liyakatın önüne koyarak eşitlik ve adalet temelinden uzak işlemler tesis etmeyi ifade etmekte olup özellikle hiyerarşik ilişki içerisinde bulunan kişiler arasındaki duygusal ilişkiler eşit durumdakiler arasındaki duygusal ilişkilere kıyasla işyerinde kayırmacılığın ortaya çıkmasına yol açabilecek niteliktedir. Bu işlemler işyerinde ödüllendirme yahut terfi ettirme, görev ve kaynakların dağıtımından yaptırım mekanizmalarının uygulanış biçimine kadar geniş bir yelpazede sayısız olanağa karşılık gelmektedir ${ }^{42}$. Ayrıca bu tür ilişkilerin gerçekleşmemiş olsa dahi diğer çalışanlar arasında eşitsizlik algısı yaratarak işyerine bağlılığı ve verimi düşürme gibi etkilerinin olduğunu da söylemek mümkündür ${ }^{43}$. Doktrinde Yıldız tarafından isabetle belirtildiği üzere aralarındaki gönül ilişkisi nedeniyle amir konumundaki işçi diğer işçiye hak etmediği halde performans değerlendirmesinden yüksek not veriyor yahut diğer çalışanların performansı daha yüksek olmasına rağmen sadece aralarındaki ilişki sebebiyle yüksek

41 9. Hukuk Dairesi’nin 29.9.2005 tarihinde verdiği kararda dosyadaki bilgi ve belgelerden davacının iddia edildiği gibi işyerinde ahlak ve iyiniyet kurallarına uymayan bir davranışını kanıtlanmadığı gibi, dışarıdaki hareketlerin de sadece dedikoduya dayandığının anlaşıldığı ifade edilerek duygusal ilişkinin kesin deliller ile ispatlanması gerekliliği vurgulanmıştır. Yargıtay 9.HD, 2203/31733, 29.9.2005 (Şahin Çil, İş Kanunu Şerhi II.Cilt (1.Bası Turhan Kitabevi 2004) 1901); Daire 2014 yllında verdiği başka bir kararında da iş sözleşmesinin haklı nedenle feshini ispat yükümlülüğünün davalı işverende olduğunu, somut olayda dava dışı şahıs ile davacı arasında özel ilişkinin varlığı ve iş düzenini bozucu eylemin bulunduğunun beyan edilmediğini ve işveren tarafından da bu konuda tutanak ibraz edilemediğini dolayısıyla haklı nedenle feshin ispat edilemediğini belirtmiştir. 9.HD, 23.05.2014, E.2012/11399, K.2014/16603 (Sinerji Mevzuat ve İçtihat Bilgi Bankası); Bununla birlikte 22. Hukuk Dairesi 2017 yılında verdiği kararında, dosya kapsamında bulunan tutanaklar ve davacıya ait aile nüfus kayıt örneği dikkate alındığında davacı ile işyerinde çalışan diğer bir işçi arasında ilişki olduğunun sabit olduğunu ancak davacı ve diğer işçi arasındaki bu tür bir ilişki toplumsal olarak kabul edilmeyen bir davranış olsa bile iş sözleşmesinin feshi noktasında İş Kanununda sayılan haklı nedenle fesih gerekçeleri arasında bulunmadığını, davacının sosyal açıdan tasvip edilemeyecek bu davranışının iş görme ediminin gereği gibi ifasını etkilediğinin de iddia ve ispat edilmiş olmadığını belirtmiştir. Ancak mahkemeye göre işverenin bu davranışı yapan davacı işçi ile iş ilişkisini sürdürmesi beklenemeyeceğinden, işverence yapılan feshin geçerli sebebe dayandığı kabul edilmelidir şeklinde hüküm tesis ederek taraflar arasındaki ilişkinin işyerinde olumsuzluk yarattığı varsayımından hareket etmiștir. Yargitay 22. HD, 17221/22711, 24.10.2017 (Sinerji Mevzuat ve İçtihat Bilgi Bankası); Aynı yöndeki karar için bkz. Yargıtay 22.HD, 17587/22860, 01.07.2015 (Sinerji Mevzuat ve İçtihat Bilgi Bankası).

42 Lale Oral Ataç ve Asiye Şahin Emir 'İş Hukuku Boyutuyla Örgütlerde Kayırmacılık’ in Prof.Dr.Sevinç Köse ve Prof. Dr.Mustafa Alp (eds) Örgütsel Davranış ve İş Hukukuna Yansımaları (Seçkin Yayıncılık 2020) 157.

Yiğit (n 1) 3778. 
not veriyorsa anılan durum üst konumunda olan işçi bakımından işverene karşı iş sözleşmesinden kaynaklanan yükümlülüğün ihlali niteliğinde olacaktır ${ }^{44}$.

İşyerlerinde örgütsel yapı içerisinde ilişkiye giren tarafların eş düzey yahut yatay pozisyonda olduğu durumlar hem diğer yöneticiler hem de çalışanlar bakımından genellikle kabul görürken, yönetici pozisyonunda bulunan kişiler ile astları arasındaki ilişkilere olumsuz yaklaşıldığı, çalışanın terfi ettiği durumlarda kayırmacılık algısının ortaya çıktığı gözlenmektedir ${ }^{45}$. Nitekim Society for Human Resources Management tarafından 2005 yılında insan kaynakları yöneticileri üzerinde yapılan bir araştırmada duygusal ilişki içerisinde bulunan departman çalışanlarının \%44'ünün kayırmacı davranışlar sergilediğinin tespit edilmiş olması dikkat çekici niteliktedir ${ }^{46}$.

Konunun Yargıtay kararlarına yansımasına baktığımızda ise yönetici-çalışan arasındaki bu tür duygusal ilişkilerin kimi hallerde iş ilişkisinde taraflar arasında bulunması gereken güven temelini sarstığından ve iş ilişkisinin sürdürülmesini çekilmez hale getirdiğinden haklı nedenle feshine kimi hallerde ise işin işleyişini ve düzenini bozduğundan bahisle geçerli sebeple feshe neden olduğu görülmektedir. Bununla birlikte bahsi geçen kararlarda mahkemenin istikrarlı bir tutum izlemediği, kayırmacılık kapsamına dahil edilebilecek benzer davranışlar ve olumsuz etkiler içermesine rağmen konuyu kimi kararlarda işverenin geçerli fesih hakkına kimi kararlarda ise haklı nedenle derhal fesih hakkına dayandırması dikkat çekici niteliktedir.

7. Hukuk Dairesi’nin 2015 yılında verdiği karara konu olan olayda bölge müdürü pozisyonundaki çalışan ile astı arasındaki ilişkinin yarattığı olumsuz etki geçerli fesih sebebi olarak değerlendirilmiştir. Kararda bölge müdürlüğü çalışanları beyanları ve dosyadaki tanık beyanları bir bütün olarak değerlendirildiğinde; davacının Bölge Müdürüyle yaşadığı gönül ilişkisi nedeniyle bazen oldukça rahat davranıp işe geç geldiği, geç saate kadar çalışmaya başlamadığı, küskün oldukları bazı zamanlarda ise işle ilgili olarak bile birbirleriyle iletişimde bulunmadıkları gibi iş akışını engelleyecek tarzda davranıp birbirlerine hakaret ettiklerinin ve çalışanların bu davranışlardan olumsuz etkilendiklerinin dosya kapsamıyla sabit olduğu, bu nedenle işyerinde davacinın eylemlerinin haklı neden ağırlığında olmasa da işyeri huzurunu bozan eylemler olduğu ve işverence iş ilişkisinin sürdürülmesi beklenemeyeceğinden feshin geçerli nedene dayandığı sonucuna ulaşılmıştır ${ }^{47}$.

22. Hukuk Dairesi’nin 2014 yılında verdiği karara konu olan olayda davacının iş sözleşmesi işyerinde beraber çalıştıkları işçi ile aralarındaki duygusal ilişkinin sona ermesi neticesinde profesyonel düzeyde iş ilişkisinin devam etmesinde problemler olması, işyerinde bunun olumsuzluklara yol açması, yöneticisi olduğu işçi ile yakınlaşması ve bu işçiye karşı olumlu yönde ayrımcılık yapması, bu konularda diğer çalışanları tehdit etmesi gerekçeleriyle haklı sebep iddiasıyla feshedilmiştir. Daire ise taraf delilleri tam olarak toplanmaksızın fesih gerekçeleri sabit kabul edilerek geçerli sebeple iş

44 Yildiz (n 33) 22.

45 Bu ilişkiler içerisinde ise kadın üst düzey erkek alt düzey olan ilişkilerin, erkek üst düzey kadın alt düzey olan romantik ilișkilere göre daha uygunsuz karşılanması, erkek üst düzey-kadın alt düzey ilişkisinin ise daha kabul edilir görülmesi dikkat çekici niteliktedir. Ömüriş ve Ehtiyar (n 12) 23.

46 İbid 21.

47 Yargıtay 7. HD, 31351/26504, 23.12.2015 (Sinerji Mevzuat ve İçtihat Bilgi Bankası) 
sözleşmesinin feshedildiğinin kabul edilmesinin yerinde olmadığını, öncelikle tarafların bildirdiği deliller toplanmasını ve bundan sonra dosya bir değerlendirmeye tabi tutularak oluşacak kanaate göre bir karar verilmesi gerektiğini belirtmiş; dosya tekemmül ettirilmeden ve dava, savunma ile yargılanma hakkına özen gösterilmeden verilen eksik incelemeye dayalı kararın bozulması gerektiğine hükmetmiştir ${ }^{48}$. 7.Hukuk Dairesinin 2016 yılında verdiği kararda yerel mahkeme, davacının takım lideri olduğu, aynı takımda bulunan kız arkadaşı ile kişisel ilişkisi itibari ile özellikle yapılan toplantı sayısının diğer çalışanların toplantı sayısına göre makul süre ve sayının çok üzerinde kaldığı, diğer çalışanlar arasında bu davranış şeklinin ciddi huzursuzluk yarattığı, dolayısı ile iş sözleşmesi karşılıklı güvene dayalı olduğundan ve işçinin sadakat ve özen yükümlülüğü bulunduğundan sözleşmenin devamının işveren yönünden çekilmez hal aldığı, eylemin 4857 sayılı yasanın 25/2-e maddesine göre güveni kötüye kullanma ,doğruluk ve bağlılığa uymayan davranış ölçüsünde olduğu davacının iş sözleşmesini feshinin haklı sebebe dayandığı yönünde karar vermiştir. Daire ise çalışanların davacı hakkındaki şikayetleri ve kız arkadaşı olan diğer çalışan ile ilgili davranışları nedeniyle davacıya 06.01.2015 tarihinde yazılı uyarı verilerek tebliğ edildiğini; bu tarihten sonra davacının olumsuz herhangi bir davranışının tespit edilemediğini ifade ettikten sonra 4857 sayılı Kanunun 19. maddesi hükmü uyarınca işverence fesih sebebinin açık ve kesin belirtilmediği gibi fesih öncesinde davacının savunmasının da alınmadığı, ihbar tazminatı ödemesiyle haklı fesih nedeninin de çelişkili olduğu ve bu hususta ispatın da mevcut olmadığı işveren feshinin haklı ya da geçerli bir nedene dayanmadığ sabit olup davacının temyiz itirazlarının yerinde olduğunu, bu nedenle feshin geçersizliğine ve davacının işe iadesine karar verilmesi gerektiği yönünde hüküm tesis etmiştir ${ }^{49}$. 22.Hukuk Dairesi tarafından 2015 yılında verilen kararda yerel mahkeme işveren tarafından feshe konu edilen davacı işçi ile aynı şubede üstü konumunda olan dava dışı şahıs arasında yaşanan ilişkinin yargılanmasının ve kabul görmemesinin mümkün bulunmasına rağmen bu durumun sadece muhatapların eş ve yakınlarını ilgilendireceğini, bu sebeplere dayanarak iş sözleşmesini feshetmesinin iş kanununda haklı bir gerekçe olarak kabul edilmediğini; iki yetişkin birey arasındaki gönül ilişkisinin banka üst düzey yetkililerine bildirilmesini beklemenin hayatın olağan akışına aykırı olduğu gibi Anayasa ve İş Kanunlarında böyle bir zorunluluğun tanımlanmadığını ifade etmiştir. Yerel mahkeme kararının temyizi üzerine Daire ise davacı ile aynı şubede üssü konumundaki dava dışı evli şahsın özel ilişki yaşadıkları, bu durum hakkında davalı bankaca bilgi istenilmesine rağmen reddedildiğinin sabit olduğunu; işverenin bu davranışı yapan işçi ile iş ilişkisini sürdürmesi beklenemeyeceğinden, işverence yapılan feshin geçerli sebebe dayandığı kabul edilerek davanın reddine karar verilmesi gerektiğini belirmiştir ${ }^{50}$. Doktrinde Yıldız tarafından isabetle belirtildiği üzere anılan karar çalışanların gönül ilişkileri hakkında işverene yazılı bilgi verme yükümlülügünün olmaması ve davalı vekili tarafından ileri sürülen şube müdürü pozisyonunda olan kişinin duygusal ilişki içerisinde bulunduğu davacının performans değerlendirmesinde objektiflikten uzak davranma ve kayırmacılık ihtimaline yönelik somut delil sunulmaksızın genel bir şüpheden hareket edilerek hüküm tesis edilmesi bakımından eleştiriye açık niteliktedir ${ }^{51}$.

48 Yargıtay 22.HD, 21677/25434, 24.9.2014 (Sinerji Mevzuat ve İçtihat Bilgi Bankası)

49 Yargitay 7.HD, 7096/12913, 08.06.2016 (Sinerji Mevzuat ve İçtihat Bilgi Bankası)

50 Yargitay 22. HD, 35211/79, 19.01.2015 (Sinerji Mevzuat ve İçtihat Bilgi Bankası)

$51 \quad$ Yildiz (n 33) 23. 
7.Hukuk Dairesi tarafından 2014 yılında verilen kararda dosyada dinlenen tanıklar, işveren tarafından alınan yazılı beyanlar ve toplanan tüm deliller birlikte değerlendirildiğinde, davacının diğer çalışan ile duygusal yakınlığının olması nedeniyle, diğer çalışanlarla bu çalışan arasında ayrımcılık yaptığı, bu kişinin daha rahat çalışmasını sağladığı, mesaiye uymamasına herhangi bir işlem yapmadığı ve bu nedenle işyerindeki çalışma barışını bozduğunun sabit olduğu, bu durumun işverene iş sözleşmesini haklı olarak tazminatsız sonlandırma imkanı verdiğini belirtmiştir ${ }^{52}$. 9. Hukuk Dairesi de 2016 yılında verdiği kararında ise duygusal ilişki yahut gönül ilişkisi kavramını kullanmamakla birlikte, işçilerin çalıştıkları departmandaki hiyerarşik yapı içerisinde ast üst ilişkilerini hiçe sayarak gayri ahlaki ilişki yaşamaları ve bunu da işyerine yansıtmaları nedeniyle 4857 sayılı yasanın 25. maddesi uyarınca iş akitlerinin sonlandırılabileceğini ifade etmiştir ${ }^{53}$.

\section{MÜŞTERILER YAHUT ÇALIŞANLARDAN BIRININ EŞi GIBi IŞYERI DIŞINDAN ÜÇÜNCÜ KişiLERLE IŞÇI ARASINDAKI DUYGUSAL ILIŞKILERIN IŞ iLIŞKISINE ETKILERI}

Duygusal ilişki evli yahut bekar işyerinde çalışanlar arasında yaşanabileceği gibi müşteri, çalışanlardan birinin eşi yahut akrabası gibi işyeri ile ilgisi olmayan üçüncü kişilerle çalışan arasında da ortaya çıkabilir. Yüksek Mahkeme’nin çalışanlar arasında olmamakla birlikte işyerinde çalışan ile üçüncü kişi olan müşteriler arasında gerçekleşen duygusal ilişkiler sebebiyle iş sözleşmesinin geçerli olarak feshinde bu ilişkinin işyerinde ve işin yürütümünde olumsuz bir etki yaratıp yaratmadığını denetlediği görülmektedir.

2015 yılında 7. Hukuk Dairesi tarafından verilen kararda davacının iddia edilen bir kısım davranış veya ilişkilerinin Avrupa İnsan Hakları Sözleşmesi ve Anayasa ile güvence altına alınan özel hayata karışmama ve saygı ilkesinin bir gereği olduğu ve fesih konusu yapılamayacağı isabetli olarak belirtilmiş ise de, davacının özel hayatı ile ilgili meselelerin davacının işine ve müşteri ilişkilerine zarar vermemesi gerektiğinin açı olduğu belirtilmiştir. Karara konu olan olayda, davacının banka teftiş soruşturması sırasında bir dönem ilişki yaşadığını kabul ettiği evli ve polis memuru olan kişi aynı zamanda bankanın müşterisi olup maaşını bankadan almakta ve bankaya ait kredi kartlarını kullanmaktadır. Sözü edilen kişi davacı hakkında bankaya vermiş olduğu şikayet dilekçesinde, kendisinin 2012 ve 2013 yıllarında eşiyle tatile çıktığı dönemlerde davacının bankaya ait kredi kartlarındaki harcamaları kontrol etmek suretiyle kendisine nerede olduğunu bildiğini belirten mesajlar attığını ve banka görevlisi olmasından faydalanarak bu şekilde kendisini rahatsız ettiğini iddia etmiştir. Banka teftiş raporunda, müşteri tarafından mesajların silinmiş olması nedeniyle sunulamadığı ancak müşterinin kredi kartı bilgilerinin davacı tarafından müşterinin izinli olduğu 25.06.2012-14.07.2012 tarihleri arasında 118 defa ve 15.06.2013 - 08.07.2013 tarihleri arasinda ise 51 defa kontrol edildiği tespit edilmiştir. Mahkeme davacının banka görevlisi olmasından faydalanarak özel hayatı ile ilgili meselelerle ilgili olarak müşterinin kişisel bilgilerine ulaştığının anlaşıldığını,

52 7.HD, 06.03.2014, E.2013/20680, K.2014/5507 (Sinerji Mevzuat ve İçtihat Bilgi Bankası)

53 Yargıtay 9.HD, 12252/20517, 21.11.2016 (Sinerji Mevzuat ve İçtihat Bilgi Bankası) 
bankanın davacının bu ve bu gibi eylemleri nedeniyle zarar göreceğinin açı olduğunu ve bu sebeple iş sözleşmesinin feshedilmesinin geçerli nedene dayandığını ifade etmiştir ${ }^{54}$.

2014 yılında 7. Hukuk Dairesi tarafindan verilen kararda, her ne kadar davacının hastaneye gelen hastalarla işyeri dışında gönül ilişkisi kurması nedeniyle şikayet edilmesi geçerli fesih nedeni ise de, mahkemece feshin geçerli fesih nedeni olduğunun gözetilmeden kıdem ve ihbar tazminatı talebinin kabulüne karar verilmesi gerekirken reddine karar verilmesi hatalıdır şeklinde hüküm tesis etmiş ve işyerine olumsuz etkileri olan üçüncü kişi durumundaki müşterilerle kurulan duygusal ilişkilerin geçerli fesih nedeni olabileceğini kabul etmiştir ${ }^{55} .2010$ yılında 9.Hukuk Dairesi tarafından verilen kararda da işçinin özel yaşamı ve ilişkilerinin işverenin ilgi alanı dışında bulunduğunun açık olduğu ancak davacı iş̧̧inin müşterisi olan evli bir erkekle özel ilişkiye girdiği, söz konusu kişinin eşi tarafından, bu münasebeti ve eşi ile kendisini tehdit ettiği için işverene şikayet edildiğinin dosya içeriğine göre sabit olduğu, şikayet üzerine idari soruşturma başlatılarak davacı ve ilgililerin beyanlarına başvurulduğu ve olayın işyeri çevresinde bilinir hale geldiği ortaya konulmuştur. İşçinin olumsuz davranışları yüzünden artık iş ilişkisi işveren açısından normal ölçülerde sürdürülemez haldedir. İhbar ve kıdem tazminatlarının ödenmiş olması durumu değiştirmeyecektir ve fesih geçerli nedene dayanmaktadır ${ }^{56}$.

Daire’nin 2018 yılında verdiği karara konu olan olayda davacı bir havayolu şirketinde pilot olarak çalışmaktadır ve aynı işyerinde kabin memuru olan E.K ile duygusal ilişki yaşamıştır. Kabin memuru E.K, davacı pilot ile ilişki yaşamadan evvel havayolu şirketinin müşterilerinden G.Y ile ilişki içerisinde bulunmuş; G.Y ise E.K’nın davacı ile birlikte olmasını kabullenemediğinden davacı ve E.K’ya çeşitli tarihlerde attığ olarak davacının da G.Y.ye tehdit ve hakaret içeren mesajlar gönderdiği tespit edilmiştir. G.Y bu mesajları işverene iletmiş ve davacı pilotun iş sözleşmesi haklı nedene dayalı olarak feshedilmiştir. Uyuşmazlık istinaf incelemesine tabi tutulmuş ve Bölge Adliye Mahkemesi davacının dava dışı G.Y. isimli kişiye ahlak ve adaba aykırı hareketlerde bulunduğu ileri sürülmesine karşı bu hareketlerin işyerinde meydana gelmediği davacı ile bu kişinin bir araya işyeri veya dışında hiç gelmedikleri davacı ile bu kişi arasındaki ilişkilerin özel yaşamlarından kaynaklandığı, davacının G.Y. ile arasında geçen olayları işyerine yansıtmadığı, çalışmasına etki etmesine izin vermediği, aksine G.Y. isimli kişinin davacıya husumet besleyerek davacıyı zayıflatacağı düşüncesi ile davacının işten çıkarılabilmesi amacıyla işverene sürekli mesajlar gönderdiği anlaşıldığından davacının toplu iş sözleşmesinin bu maddesi kapsamında kalacak bir hareketinin bulunmadığı, bu maddelere göre davacının iş sözleşmesinin feshedilemeyeceği, davalı işverenin davacıya isnat olunan hareketler nedeniyle iş ilişkisinin davalı şirket açısından çekilmez hale geldiği yönünde dosyaya bir delil sunmadığı, davacı işçinin özel yaşamındaki bu yaşananları işyerine yansıtmadı̆̆ı, aksine dava dışı G.Y. isimli kişinin davacıya zarar verebilmek amacıyla sürekli işverene mesaj göndermek suretiyle davacı aleyhinde harekette bulunduğu geçerli bir fesih nedeni de bulunmadığ bu sebeple de davacının iş sözleşmesinin geçerli sebeple feshedilemeyeceğine hükmetmiştir. Temyiz incelemesi yapan 9.

54 Yargıtay 7.HD, 28037/26718, 24.12.2015 (Sinerji Mevzuat ve İçtihat Bilgi Bankası).

55 Yargitay 7. HD, 5561/14474, 26.06.2014 (Sinerji Mevzuat ve İçtihat Bilgi Bankası)

56 Yargitay 9.HD, 37801/36261, 6.12 .2010 (Sinerji Mevzuat ve İçtihat Bilgi Bankası) 
Hukuk Dairesi ise, davacının G.Y.'nin eşine ve kendisine yönelik tehdit ve hakaret içeren whatsapp mesajlarını içeren yazışmalarının G.Y. tarafından bir maille davalı işveren yetkililerine bildirildiği, bu mail üzerine davalının olaylardan haberdar olduğu, tarafların birbirlerine gönderdiği mesajların çirkin içeriği, işyerinden istifa ederek ayrılan E.K’nın davalı işverenin başka bir çalışanı olduğu hususları da gözetildiğinde taraflar arasındaki olumsuzluğun işyerine de yansıdığı, yaşanan olayların davalı işveren iş ilişkisinin sürdürülmesi açısından önemli ve makul ölçüler içinde beklenemeyecek hale gelmesine neden olduğu, feshin bu suretle geçerli nedenlere dayandığını ifade etmiştir ${ }^{57}$. Anılan kararda işverenin dava dışı G.Y ile davacı işçi arasında yaşanan olaylardan G.Y’nin gönderdiği mesajlar neticesinde haberdar olmasına dek geçen süreçte iş ilişkisine herhangi bir yansıması olmadığı anlaşılmaktadır. Bu yönüyle Bölge Adliye Mahkemesi’nin ulaştığı sonucun Anayasa Mahkemesỉnin H.Ç ve Esra Ünlü başvurularında tespit ettiği esaslar ile uyumlu olduğu ve işçinin özel hayatına saygı hakkının korunması bakımından etkin olduğunu ifade etmek mümkündür ${ }^{58}$.

Yüksek Mahkeme’nin çalışanlar arasında olmamakla birlikte işyerinde çalışan ile üçüncü kişi olan müşteriler arasında gerçekleşen duygusal ilişkileri somut olayın özelliğine göre işveren ile işçi arasında bulunması gereken güven temelinin sarsıldığından bahisle haklı fesih sebebi olarak değerlendirdiği kararları da bulunmaktadır. Yargıtay Hukuk Genel Kurulu’nun 2000 yılında verdiği karara konu olan olayda işçilerden biri iş arkadaşının eşi ile duygusal ilişki içerisine girmiş ve arkadaşı mesaide iken onun eşi ile arkadaşının evinde ilişkide bulunmuş, suçüstü yakalanmış ve tutuklanmıştır. Hukuk Genel Kurulu işçilerden birinin eşi ile diğer işçinin ilişkiye girmesinin, işyerindeki çalışma düzenini olumsuz şekilde etkileyeceği, iş barışını bozarak verimi düşüreceğinin kabul edilmesi ve davacının söz konusu eyleminin ahlak ve iyiniyet kurallarına uymayan bir hal olarak değerlendirilmesi gerektiğini, bu itibarla işyeri dışında işlenen bir suç olarak kabul edilmesinin uygun olmadığını ifade etmiştir ${ }^{59}$.

Yeni tarihli kararlarda ise Yargıtay'ın sadece işçinin müşteri ile ilişkisini haklı fesih sebebi olarak yeterli görmediği, güven ilişkisini sarsan başka unsurların bu ilişki ile birlikte veya ilişki sonucu bulunmasını da aradığı söylenebilir.9. Hukuk Dairesi 2013 yılında verdiği kararında davacının savunması değerlendirildiğinde duygusal yakınlık yaşadığı şahsın maaş yazısını getirdiği firmada çalışmadığını bildiği ancak buna rağmen o belgeyi kabul ettiği, davacının davranışının doğruluk ve bağlılığa uymayan davranış niteliğinde olduğu ve feshin haklı nedene dayandığı anlaşıldığından davanın kabulü yerine reddi hatalı olup bozma nedeni olduğunu belirterek bankada çalışan işçinin duygusal ilişki içerisinde olduğu kişiye usulsüz olarak kredi girişi yapmasını doğruluk ve bağlılığa uymayan bir davranış olarak nitelendirmiştir ${ }^{60}$. 22. Hukuk Dairesi tarafından 2016 yılında verilen kararda da işçinin, Ayrancı-1 mağazasında devamlı alışveriş yapan bir bayan müşteriden şirket çalışma prensiplerine aykırı olarak cep telefonu numarası istemesi ve akabinde müşteri ile özel olarak görüşmek istediğini belirterek evli olduğu halde kendisini bekar olarak tanıtmak sureti ile

57 Yargıtay 9.HD, 26396/12470, 04.06.2018 (Sinerji Mevzuat ve İçtihat Bilgi Bankası)

58 Aynı yöndeki görüş için bkz. Civan (n 32) 183.

59 Yargıtay HGK, 9-1100/1155, 20.09.2000 (Sinerji Mevzuat ve İçtihat Bilgi Bankası); Doktrinde Yiğit, anılan kararın isabetli olduğunu belirtmektedir Yiğit (n 1) 3792; Aynı yöndeki karar için bkz. Yargıtay 9.HD, 18248/44, 26.01.2000 (Sinerji Mevzuat ve İçtihat Bilgi Bankası)

60 Yargitay 9.HD, 2620/20522, 04.07.2013 (Sinerji Mevzuat ve İçtihat Bilgi Bankası) 
şirket itibarını zedelediği eylemin haklı fesih sebebi olarak değerlendirilebileceği ancak her ne kadar davalı işveren tarafından eylemlerin gerçekleştiği tarihten itibaren altı iş günü içerisinde haklı fesih sebebi yapılmamış ise de geçerli feshe dayanak teşkil edeceği gözetilerek davalı delillerinin buna göre değerlendirilerek oluşacak sonuca göre karar verilmesi gerektiği ifade edilmiştir ${ }^{61}$. Dava konusu olayda işçinin anılan eylem dışında işyerinde satılan ürünü parasını ödemeden yemesi, sözlü uyarılara rağmen 15.12.2008 ve 09.01.2009 tarihlerinde görev başında iken cep telefonu kullanması, 24.09.2009 tarihinde çalışan bayan personel ile aşırı samimiyet kurması, 16.02.2009 tarihinde bayan müşteriye “dişlerin takma mi, gerçek mi?” diyerek müşteriyi rahatsız etmesi, 26.02.2014 tarihinde mutfak personeli olarak çalışan bayan personele küfür etmesi şeklinde farklı eylemlerinin söz konusu olması da dikkat çekici niteliktedir.

İş Kanunu md.25/IV bendi uyarınca işçinin gözaltına alınması yahut tutuklanması halinde devamsızlığın 17 maddede belirtilen bildirim süresini aşması haklı bir fesih nedeni olup işçinin gözaltına alınmasına yahut tutuklanmasına sebep olan olayın işyerinde yahut işyeri dışında gerçekleşmesi, işçinin kusurlu yahut kusursuz olması önem taşımayacaktır ${ }^{62}$. İşyeri dışında ve işyerinde çalışmayan kişilerle yaşanan duygusal ilişkilerin olumsuz etkilerinin işyerine sirayet etmesinin özellikle işyeri dışında yaşanan cinsel ilişki sonucunda işçinin gözaltına alınması yahut tutuklanması ve İş Kanunu md.25/IV uyarınca devamsızlığın 17 nci maddedeki bildirim süresini aşması biçiminde tezahür etmesi işverene iş sözleşmesini derhal sona erdirme yetkisi vermektedir ${ }^{63}$. Nitekim 9.Hukuk Dairesi’nin 2009 yılında verdiği kararda davacının, küçük yaşta bir kızla cinsel birliktelik kurduğunun anlaşıldığı; davacının bu eyleminin, sonucu itibari ile işyerinde olumsuzluklara yol açacağının açık olduğu ve işverenin feshinin 4857 sayılı İş Kanunu m. 25/IV’ün unsurlarını taşıdığının kabul edilmesi gerektiği ifade edilmiştir ${ }^{64}$.

\section{DUYGUSAL ILIŞKININ TARAFLARININ EŞLERI YAHUT YAKINLARININ IŞYERINE SIRAYET EDEN DAVRANIŞLARININ IŞ ILIŞKISINE ETKILERI}

İşin yürütümü ve işyerinin huzuru ile işleyişine yönelik olumsuz etki duygusal ilişkinin taraflarınca işyerine yansıtılmamış olsa dahi, tarafların eşleri, anne yahut babaları gibi yakınlarının işyerine sirayet eden davranışları neticesinde de ortaya çıkmış olabilir. 7. Hukuk Dairesỉnin 2015 yılında verdiği kararına konu olan olayda davacının bölge müdürü olarak davalı şirkette çalıştığ olmasına rağmen bölgedeki başka bir mağazanın müdürü ile duygusal ilişki içinde olduğu, kadının eski eşinin işyerine gelerek olay çıkardığı ve yazılı şikayette bulunduğu anlaşılmaktadır. Bu açıklamalar doğrultusunda, davacının emri altındaki personelle özel ilişkisinin işyerine yansıdığı, bu

61 Yargıtay 22. HD, 12190/13912, 9.5.2016 (Sinerji Mevzuat ve İçtihat Bilgi Bankası)

62 üzek İş Hukuku (n 14) 730.

63 Doktrinde Keser, işyeri dışında yaşanan bir cinsel birlikteliğin işyerine olumsuz yansıması bulunması durumunda işçinin iş sözleşmesinin ancak işçinin davranışlarından kaynaklanan geçerli sebep ile feshedilebileceği görüşündedir. Keser (n 5) 25.

64 Yargıtay 9.HD, 11072/127, 19.1.2009 (Sinerji Mevzuat ve İçtihat Bilgi Bankası) 
durumun işin yönetimi ve işleyişinde olumsuzluklara neden olacağ ve iş ilişkisini sürdürmesinin davalı işverenden beklenemeyeceği açık olup feshin geçerli nedene dayandığg kabul edilmelidir ${ }^{65}$.

2017 yılında verilen karara konu olan olayda ise davacının işyerinde başka bir çalışanla gönül ilişkisi olduğuna dair dedikodu yapıldığını duyması üzerine, bu dedikodudan sorumlu tuttuğu işyeri çalışanının üzerine yürümüş ancak araya girenler olmasıyla olay bu aşamada yatışmıştır. Fakat konunun davacının kocasına da intikali üzerine bu defa davacının kocası yanında başkaları da olduğu halde işyerine gelerek olay çıkartmıştır. Mahkemeye göre bu durumda sonuç itibariyle davacı hakkında çıkan dedikodunun işyerinde olumsuzluklara yol açtığı tartışma dışı olup feshe konu eylemin işyerinde olumsuzluklara yol açtığının belirlenmesi karşısında davalı işverenin feshinin geçerli nedene dayandığının kabulü gerekmektedir ${ }^{66}$. Anılan kararda dedikodu yayılmasına sebebiyet veren işçi hakkında işveren tarafından herhangi bir yaptırım uygulanmadığı görülmektedir. Oysa ileride değinileceği üzere Yargıtay’n kimi kararlarında işyerinde çalışan diğer işçilerce duygusal ilişki olduğu yönünde dedikodu yayılması da işverene haklı fesih imkanı veren sataşma fiilleri arasında görülmektedir.

\section{DUYGUSAL ILIŞKININ TARAFLARININ IŞYERINDE ALENI BIR BIÇIMDE DUYGULARINI GÖSTERICI NITELIKTE DAVRANIŞLARDA BULUNMALARININ IŞ ILIŞKISINE ETKILERI}

Duygusal ilişkinin taraflarının işyerinde aleni bir şekilde duygularını gösterir nitelikte öpüşme, sarılma, kucaklaşma, kucak kucağa bulunma gibi davranışlarının Yargıtay tarafından ağırlıklı olarak işvereni ilgilendirdiği, doğruluk ve bağlılığa uymayan davranış olduğu gerekçesi ile haklı fesih sebebi kapsamında değerlendirildiği görülmektedir. 9. Hukuk Dairesi’nin 2019 yılında verdiği kararda, dosyadaki bilgi ve belgelerden işyerinde müdür yardımcısı olarak görev yapan davacı işçinin evli olan diğer bir kadın çalışan ile duygusal ilişki içine girdiği, işyerine ait elektronik postayı kullanarak yazıştığı, en son olarak kadın çalışan ile işyerinde öpüştüğü, bu durumun güvenlik kameraları tarafından kaydedildiği, duruma güvenlik kameralarının kaydı nedeni ile vakıf olan davalı işverenin davacı işçiyi bu fiili nedeniyle işten çıkarttığı tespit edilmiş ve özel hayat ve özel hayatın gizliliği kuralının iş yerinde ve başka bir çalışana karşı alenen yapılan fiili kapsamadığına, feshe konu edilen davranışta kadın iş̧̧inin rızasının olup olmadığı hususu tam olarak açıklığa kavuşturulamasa da, davacı işçinin evli olan başka bir çalışan ile işyerinde yukarıda açıklanan şekilde bir olay yaşamasının başlı başına doğruluk ve bağlılık ile bağdaşmayan hal olup, işverenin haklı nedenle sözleşmeyi derhal feshinin haklı olduğuna karar verilmiştir ${ }^{67} .2020$ yılında Daire tarafından verilen bir başka kararda da dosyadaki bilgi ve belgelerden davalı işyerinde satış temsilcisi olarak görev yapan davacı işçinin aynı işyerinde bulunan kadın çalışan ile duygusal ilişki içine girdiği, en son olarak kadın çalışanı iş yerinde öpmeye çalıştığı, bu durumun güvenlik kameraları tarafından kaydedildiği, duruma güvenlik kameralarının kaydı nedeni ile vakıf olan davalı işverenin davacı işçiyi bu fiili nedeniyle işten çıkarttığının anlaşıldığı; özel hayat ve özel hayatın gizliliği kuralının işyerinde ve başka bir çalışana karşı alenen yapılan

65 Yargitay 7.HD, 22993/21580, 05.11.2015 (Sinerji Mevzuat ve İçtihat Bilgi Bankası)

66 Yargitay 9.HD, 25634/15797, 16.10.2017 (Sinerji Mevzuat ve İçtihat Bilgi Bankası).

67 Yargıtay 9.HD, 30145/3397, 12.02.2019 (Sinerji Mevzuat ve İçtihat Bilgi Bankası) 
fiili kapsamadığı feshe konu edilen davranış kadın işçi tarafından da savunma tutanağında kabul edilmişken, davacı işçinin işyeri ortamında başka bir çalışan ile yukarıda açıklanan şekilde bir olay yaşamasının işyeri kurallarına ve genel ahlak kurallara aykırı olduğundan davalı işveren feshinin haklı nedene dayandı̆̆ ifade edilmiştir ${ }^{68}$.

Daire’nin 2010 yılında verdiği kararda evli olan davacının işyerinde, mesai saatleri içerisinde yine davalı işverenin işçisi ile karanlık haldeki numune odasında uygunsuz vaziyette yakalandığının taraflar arasında ihtilafsız olduğu ve Mahkeménin kabulünde olduğu, evli olan davacının iş sözleşmesinin işveren tarafından ahlaka aykırı olduğu tartışmasız bulunan bu eylemi nedeni ile süresinde feshinin haklı nedene dayandığı ifade edilmiştir ${ }^{69}$. 1475 sayılı Kanunun yürürlükte olduğu 2002 yılında verdiği kararda da Daire, işyerinde çalışma saatleri içerisinde bir başka işçi ile kucak kucağa otururken yakalanan işçinin iş sözleşmesinin feshinin md.17/2-d bendi kapsamında doğruluk ve bağlılığa uymayan, işverenin güvenini kötüye kullanan davranış niteliğinde olduğu ifade etmiştir ${ }^{70}$.

9. Hukuk Dairesi tarafından 2005 yılında verilen kararda ise işçinin çalıştığı işyerinde bulunan misafirhaneye özel misafirini getirmesi işveren açısından iş sözleşmesinin bildirimsiz feshinde kullanılabilecek bir haklı sebep olarak kabul edilmiştir ${ }^{71}$. 7. Hukuk Dairesinin 2014 yılında verdiği kararda işçilerin işyeri sınırları içerisinde yakınlaşmaları ve cinsel birliktelikte bulunmalarının işveren bakımından haklı nedenle feshe imkan tanıyacağı belirtilmiştir ${ }^{72}$. 9. Hukuk Dairesi tarafından 2020 yılında verilen bir kararda da somut uyuşmazlıkta, davalı işveren tarafından dosyaya sunulan ve otel güvenlik kamera kayıtlarını içeren CD’nin bilirkişi tarafından çözümlendiği ve davacının mesaisinin olduğu 08.09.2013 tarihindeki görüntülerde; otele gece 02:10:53’te giriş yapan kadın müşteri ile davacının ilgilendiğinin ve lobide yakınlaştıklarının, kadın müşteri ile birlikte otel odasına girdiklerinin ve 22 dakika odada kaldıklarının, davacının kadın müşteriyi samimi bir şekilde taksiye bindirdiğinin, sonrasında otele dönerek tekrar aynı odaya girdiğinin tespit edildiğinin anlaşıldığı ifade edildikten sonra bu durum doğruluk ve bağlılı̆̆a uymayan davranış olarak nitelendirilmiş; işçinin savunmasının alınmamasının feshi haklı olmaktan çıkarmayacağına hükmedilmiştir ${ }^{73}$. Doktrinde Ergin tarafından da belirtildiği üzere bu davranışların 4857 sayılı İş Kanunu md.2'de yer verilen tanım ile sınırları çizilen işyerinde ve bu bağlamda işyeri içerisindeki misafirhanede, lojmanda veya işyerinin eklentisi durumunda olan depoda yahut numune odası gibi yerlerde gerçekleşmesi genel olarak haklı fesih nedeni olarak kabul edilmektedir ${ }^{74}$.

9. Hukuk Dairesinin 2014 yılında aksi yönde bir kararına konu olan olayda işçi özel ziyaretçisini fabrikanın depo alanına kabul etmiş, bu alanda 4-5 saat boyunca birarada bulunmuşlar ve samimi

68 Yargıtay 9. HD, 33799/19760, 23.12.2020 (Sinerji Mevzuat ve İçtihat Bilgi Bankası)

69 Yargıtay 9.HD, 21894/8111, 25.03.2010 (Sinerji Mevzuat ve İçtihat Bilgi Bankası).

70 Yargıtay 9.HD, 10696/25071, 25.12.2002 (Ercan Akyiğit, İçtihat ve Açıklamalı 4857 Sayılı İş Kanunu Şerhi, I.Cilt, (3.Baskı Seçkin Yayıncılık 2008) 1216)

71 Yargitay 9.HD, 5379/35371, 08.11 .2005 (Çil (n 40) 1894)

72 Yargıtay 7.HD, 13113/23193, 24.12.2014 (Sinerji Mevzuat ve İçtihat Bilgi Bankası).

73 Yargıtay 9.HD, 12350/1151, 03.02.2020 (Sinerji Mevzuat ve İçtihat Bilgi Bankası)

74 Ergin Gönül İlișkisi (n 3) 76. 
fotoğraflar çektirmişlerdir. Yerel mahkeme, her biri evli olan bu kişilerin ilişkilerinin arkadaşlık seviyesinden son derecede ileri bir seviyede olduğunu, nitekim davacının da savunmasında aralarında duygusal yakınlık olduğundan söz ettiğini, davacının işsözleşmesine aykııı davranışları ile sözleşmeden kaynaklanan birden fazla borcunu ihlal ettiğini, davacının iş görme borcuna aykırı davrandığı gibi sadakat borcuna da aykırı davrandığını, güven ilişkisinin temelden sarsıldığını iş sözleşmesinin md.25/II-e bendi kapsamında haklı nedenle derhal feshedebileceğini kabul etmesine rağmen 9.Hukuk Dairesi davalı işverenin feshe dayanak olarak gösterdiği "ziyaretçi girişçıkış talimatının" davacı işçiye tebliğ edildiğine dair herhangi belge bulunmadığını, kaldı ki davalı tanığı olarak dinlenen ve davalı işyerinin insan kaynakları yöneticisinin duruşmadaki beyanında “.ziyaretçilerin fabrikaya nasıl gireceklerine ilişkin yönetmeliğin olup olmadığın bilmediğini...” bildirdiğini, tüm bu hususlar ve dosyadaki diğer bilgi ve belgeler birlikte değerlendirildiğinde davacının söz konusu eylemi neticesinde iş sözleşmesinin feshedilmesinin ölçülülük ilkesi ile de bağdaşmadığını, bu nedenle feshin haklı veya geçerli bir nedene dayanmadığı gözetilmeksizin, davanın kabulü yerine yazılı gerekçelerle reddine karar verilmesinin hatalı olduğunu ifade etmiştir ${ }^{75}$.

9.Hukuk Dairesi’nin 2009 yllında verdiği kararda da somut olayda, işyerindeki öpüşme olayı ile ilgili her hangi bir şikayet olmadığı halde, işveren tarafından kamera kaydı ile tespit olunan görüntülere dayanılarak, davacının iş sözleşmesi feshedilmiştir. Karara göre davacı ve erkek arkadaşının, davalı işyerinde öpüştügüu, taraflar arasında çekişmesiz olmakla birlikte, öpüşme eyleminin anlık oluşu, işyerinde müşteri bulunmayışı, olayı bir başka çalışan işçinin de görmeyişi gözönünde tutulduğunda olayın bu oluşum şekliyle iş düzenini bozucu nitelikte bir eylem olarak kabulü ağır bir sonuç olup ölçülülük ilkesi ile de bağdaşmamaktadır. Davacının davranışı işyerinde olumsuzluklara yol açmadığından ve iş ilişkisinin devamını etkilemediği ve feshin geçerli nedene dayanmadığ anlaşılmışıtı ${ }^{76}$. Bahsi geçen bu karar Yüksek Mahkeme’nin Anayasa Mahkemesi tarafından H.Ç ve Esra Ünlü başvurusu ile belirlenen esaslar ile paralel bir biçimde hareket etmesi ve yaşanan duygusal ilişki işyerinde aleni olarak sevgi gösteren davranışları içerse dahi işyerine olumsuz bir yansıması olup olmadığının somut delillerle ortaya konulması gerekliliğini içermesi bakımından dikkat çekici niteliktedir ${ }^{77}$.

75 Yargıtay 9.HD, 16418/33973, 13.11.2014 (Sinerji Mevzuat ve İçtihat Bilgi Bankası).

76 Yargitay 9.HD, 36337/6945, 16.03.2009 (Sinerji Mevzuat ve İçtihat Bilgi Bankası)

77 İşyerinde olumsuzluğa yol açmayan duygusal ilişkileri geçerli fesih sebebi kabul etmeyen Daire’nin 2005 yllında verdiği bir başka karara konu olan olayda da dosyadaki bilgi ve belgelere göre, davacının özel ilişki içinde bulunduğu belirtilen Genel Müdür Yardımcısının işsözleşmesi 17.01.2005 tarihinde sona ermiştir. Davacının adı geçen ile yıllardır birlikte çalışı̆ğı ve tek davalı tanık beyanına göre, aralarındaki ilişkinin yıllardır olduğu ve bilindiği anlaşılmaktadır. Davacı işçinin iş sözleşmesinin feshinden önce görev yerinin değiştirilmesine de karar verildiği görülmektedir. Uzun yıllardır ve aynı genel müdür yardımcısı ile çalışan davacının iş ve özel ilişkisini yıllardır bildiği anlaşılan davalı işverenin, genel müdür yardımcısı ayrıldıktan sonra davacının iş sözleşmesini bu nedenle feshetmesi, doğru bir yaklaşım değildir. Somut bu maddi olgulara göre, davalı işveren, davacının davranışlarından kaynaklanan nedenlerin işyerinde olumsuzluklara yol açtığını kanıtlamış değildir. Daire’ye göre davacının iş sözleşmesinin feshi geçerli nedene dayanmamaktadır. Yargıtay 9.HD, 33676/36676, 21.11.2005 (Sinerji Mevzuat ve İçtihat Bilgi Bankası) 


\section{DUYGUSAL ILIŞKI ESNASINDA YAHUT SONA ERMESINDEN SONRA IŞYERINDE HUSUMETE DAYALI GELIŞEN DAVRANIŞLARIN IŞ ILIŞKISINE ETKILERI}

İşyerinde yaşanan duygusal ilişkilerin husumete dayalı ve özellikle ilişki sona erdikten sonra işçinin kişilik haklarını zedeleyici nitelikte davranışların ortaya çıkmasına sebep olması söz konusu olabilmektedir. Bu gibi durumların ortaya çıktığı hallerde işverenin fesih hakkını İş Kanunu md.25/ II-d alt bendi uyarınca işçinin işverenin başka bir işçisine sataşması hükmüne dayandırmasının mümkün olup olmadığının tartışılması gerekmektedir. Haklı bir fesih nedeni olarak sataşmanın ne şekilde gerçekleşeceği konusunda yasada bir açıklık getirilmediğinden sözle yahut davranışla ortaya çıkabileceği kabul edilmektedir ${ }^{78}$. Doktrinde Mollamahmutoğlu/Astarlı/Baysal tarafından da belirtildiği üzere işyeri dışında yaşanan ve sataşma teşkil eden davranışlar diğer işçilere karşı ise işyeri ile ilgili olduğu, işyerindeki çalışma düzenini etkilediği ölçüde haklı neden olarak kabul edilebilecek; işyeri düzenini ilgilendirmeyen ve etkilemeyen sataşma tarafların kişisel alanında kalacağından işverenin hakimiyet alanına girmeyecektir ${ }^{79}$.

Duygusal ilişkinin taraflarından birinin ilişkiyi sonlandırmak istemesi üzerine yahut ilişki devam ederken ortaya çıkan anlaşmazlıklar sonucu işyerinde meydana gelen kavgaların Yargıtay tarafından sataşma kapsamında değerlendirildiği görülmektedir. 9. Hukuk Dairesi’nin 2014 yılında verdiği karara konu olan olayda davacı ile aynı işyerinde çalışan E. adlı çalışan arasında duygusal ilişki bulunduğu, aralarındaki güven sorununu işyerine yansıttıkları, E. ile görevlendirilen bayan çalışanların davacı tarafından "ne yaptınız, ne konuştunuz" gibi sorularla rahatsız edildiği, olay günü de davacının yine E. ile görevlendirilen S. adlı çalışanı telefonla mesaj göndererek rahatsız ettiği, S.nin ağlayarak insan kaynakları sorumlusuna gittiği, konunun görüşülmesi için toplantı yapıldığı, toplantı sırasında sinirli olan davacının S.ye tokat attığı, S. nin de karşılık verdiği, yaşanan tartışma nedeniyle S.nin baygınlık geçirdiği, işyeri çalışanlarının bağrışmalar üzerine olay yerine geldikleri ve kavgayı ayırmaya çalıştıkları, davacı tanıklarının olayın başlangıcını görmedikleri, bu nedenle olayı bizzat gören davalı tanığı beyanına üstünlük tanınması gerektiği, davacının işverenin diğer çalışanına sataştığı sabit olduğu olayda Yargıtay, davacının dava dışı S. ile aralarında geçen olayın karşılıklı hakaret ve saldırı boyutuna taşındığı, işverenin olayın taraflarından birini işten çıkarıp, davacıya fiili olarak sataşmada bulunduğunu dosyada bulunan imzalı beyanı ile ifade eden diğer işçi hakkında aynı yaptırımı uygulamamasının eşit işlem borcuna aykırılık oluşturduğu göz önüne alındığında, aynı olaya karışanlara farklı davranılmasının feshi haksız kılacağı ve davacının kıdem ve ihbar tazminatına hak kazandığı̆ gözetilmeksizin yazılı şekilde hüküm kurulmasının yerel mahkeme kararını bozmayı gerektirdiğine hükmetmiştirin ${ }^{80}$

78 Hediye Ergin, 'İşçinin İşyerinde Çalışan Diğer Bir İşçiye Sataşması Nedeniyle İş Sözleşmesinin İşveren Tarafından Feshi' (2015) 34 Sicil İş Hukuku Dergisi 75; Sezgi Öktem Songu, 'Bir Haklı Fesih Sebebi Olarak Sataşma’ (2018) 39 Sicil İş Hukuku Dergisi 120; Nurşen Caniklioğlu ve Merve Akkaya, 'Yargıtay Kararları Işı̆̆ında İşyerinde Kavga Sebebiyle İş Sözleşmesinin Feshi’ in Prof.Dr.Alpay Hekimler (eds) Festschrift für Otto Kaufmann Armağanı (Legal Yayıncllık 2021) $164 \mathrm{vd}$.

79 Hamdi Mollamahmutoğlu, Muhittin Astarlı ve Ulaş Baysal, İş Hukuku (6.Baskı Turhan Kitabevi 2014) 843.

80 Yargitay 9.HD, 6650/12926, 16.04.2014 (Sinerji Mevzuat ve İçtihat Bilgi Bankası). 
Duygusal ilişki içerisinde bulunan işçilerden birinin diğer hakkında espri boyutunu aşan, kişilik haklarını zedeleyici nitelikte söz ve davranışlarda bulunması ve bunu diğer işçilerle paylaşması da sataşma kapsamında haklı fesih sebebi olarak değerlendirilmektedir. 7. Hukuk Dairesi’nin 2014 yılında verdiği karara konu olan olayda davacı hakkındaki şikayet dilekçeleri, mesajlar, tanık ifadeleri ve tüm dosya kapsamından davacının aynı işyerinde çalışan Ç. ve O. ile duygusal ilişki kurduğu ancak ikisi ile de ilişkisinin olduğunun anlaşılmasından sonra her ikisi hakkında kişisel haklarını zedeleyici nitelikte konuşmaları işyerinde yaydığı ve bunun üzerine adı geçen Ç. ve O'nun davacıyı işverene şikayet ettikleri ve işverenin de sözleşmeyi feshettiği anlaşılmaktadır. Daire’ye göre 4857 sayılı İş Kanunu 25/II-d maddesine göre işçinin işverene yahut onun ailesi üyelerinden birine yahut işverenin başka işçisine sataşması, işyerine sarhoş yahut uyuşturucu madde almış olarak gelmesi ya da işyerinde bu maddeleri kullanması işveren açısından haklı fesih nedeni teşkil etmektedir; işçiler arasında basit bir şakalaşmanın ötesine geçen Ç. ve O’nun kişilik haklarını zedeleyecek söz ve davranışların birbirleriyle ve başka işçilerle de paylaşılması karşısında olayın kendisine iletildiği işveren tarafından işyerine de yansıyan eylem nedeniyle sözleşmenin haklı nedenle feshedildiği dikkate alınmaksızın yargılama aşamasında arkadaşlar arasında şakalaşma şeklinde nitelendirilerek kıdem ve ihbar tazminatı talebinin kabulüne karar verilmesi hatalı olup, bozma nedenidir ${ }^{81}$.

Doğrudan duygusal ilişkinin taraflarından birince gerçekleşmese dahi işyerinde çalışan diğer iş̧̧ilerce duygusal ilişki olduğu yönünde dedikodu yayılması da işverene haklı fesih imkanı veren sataşma fiilleri arasında görülmektedir. 9.Hukuk Dairesi’nin 2019 yılında verdiği karara konu olan olayda dosyadaki bilgi ve belgelerden davacının iş arkadaşı kadın işçi Z.T.ye "amirin yalakası, dost hayatı yaşıyorsunuz, seni onun için koruyup gözetiyor" dediği, bunun ilgili olarak işverene verilen şikayet dilekçelerinde, davacının, evli olan Z.T. ve T.Ö.' nün aralarında dost hayatı yaşadıklarına dair dedikodular yaptığı ve bu hususun yönetime intikal ettiği anlaşılmıştır. Daire’ye göre davacının bu davranışı 4857 sayılı Yasanın 25/II-d maddesi gereği işyerinde başka bir işçiye sataşma olup işverene haklı fesih imkanı vermektedir ${ }^{82}$. Daire’nin 2017 yılında verdiği kararında işyerinde çalışan işçilerden birinin, diğer işçi hakkında işyeri ortağı olan işveren ile yemeğe çıtıkları ve tatile gittiklerini kendisine anlattığını ifade etmesi ve bu durumu işyerine gelip gidenlere de beyan ederek işyerinde aralarında ilişki olduğu yönünde dedikodular çıkmasına sebep olmasını 4857 sayılı İş Kanunu’nun 25/II-d bendinde düzenlenen "Isş̧̧inin işverene yahut onun ailesi üyelerinden birine yahut işverenin başka iş̧̧isine sataşması” niteliğinde kabul etmiştir ${ }^{83}$. 22. Hukuk Dairesi’nin 2015 yılında verdiği karara konu olan olayda işyerinde çalışan iki işçi arasında ilişki olduğu ve bu kişilerin işyerinde kasa ofisi bölümünde uygunsuz bir halde görüldükleri hususunda dedikodu yayıldı̆̆ı, davacının vazifesi olmamasına rağmen güvenlik görevlisinden kasa ofisini gösteren kamera kayıtlarına bakılarak durumun tespitini harici olarak istediği, davalı işverenlikçe yapılan soruşturmada, davacının yazılı olarak verdiği savunmasından tanık Ş. A.'in beyanından ve dosyadaki diğer bilgi ve belgelerden anlaşılmaktadır. Daire’ye göre hakkında dedikodu çıkarılan işçilerden biri evli olup, söz konusu dedikodunun kaynağının davacı olduğu tanık beyanları ve dosyada mevcut ayrıntılı ve tutarlı yazılı

81 Yargitay 7.HD, 25515/4086, 18.02.2014 (Sinerji Mevzuat ve İçtihat Bilgi Bankası).

82 Yargıtay 9.HD, 12550/14617, 01.07.2019 (Sinerji Mevzuat ve İçtihat Bilgi Bankası)

83 Yargitay 9.HD, 6203/16421, 23.10.2017 (Sinerji Mevzuat ve İçtihat Bilgi Bankası) 
ifadelerle sabittir. Davacının söz konusu davranışı diğer iki çalışana yönelik sataşma mahiyetinde olup işveren tarafindan yapılan fesih haklı sayılmalıdır ${ }^{84}$.

\section{EVLI işÇILERIN YAŞADIĞI DUYGUSAL ILIŞKILERIN IŞ ILIŞKISINE ETKISI}

Yargıtay’nn genel olarak bekar işçiler arasında yaşanan duygusal ilişkilere kıyasla evli işçiler arasındaki ilişkilere daha katı bir biçimde yaklaştığı ve işyeri dışında gerçekleşse dahi somut olayın özellikleri çerçevesinde işverene haklı yahut geçerli nedenle fesih imkanı tanıdığı, bu tür ilişkilerin çalışma düzenini bozduğu yönünde bir varsayım geliştirdiği; bazı kararlarında ise Anayasa Mahkemesi ile paralel bir tutum sergileyerek duygusal ilişkinin işe, işyerine yahut çalışma düzenine olumsuz etkilerinin bulunup bulunmadığını dikkate aldığı görülmektedir ${ }^{85}$.

22. Hukuk Dairesi tarafından 2017 yılında verilen karara konu olan olayda davacının iş sözleşmesi aynı işyerinde çalışan bir başka işçi ile evli olmasına karşın yoğun duygusal ilişkiye girdikleri, yemek saatlerinde samimi yaklaştıkları, hatta davacının bu ilişkiden 5 aylık hamile olduğu, bu durumun işyerinde dedikoduya sebep olduğu, bu durumun işverenin prestijini de sarstığı eylemin 4857 sayılı İş Kanunu'nun 25/II-b, c, e maddesindeki kurallarını ihlal ettiği gerekçesi ile haklı sebeple feshedilmiştir. Yüksek Mahkeme, dosya kapsamında bulunan tutanaklar ve davacıya ait aile nüfus kayıt örneği dikkate alındığında davacı ile işyerinde çalışan diğer bir işçi arasında ilişki olduğunun sabit olduğunu ancak davacı ve diğer işçi arasındaki bu tür bir ilişki toplumsal olarak kabul edilmeyen bir davranış olsa bile iş sözleşmesinin feshi noktasında İş Kanununda sayılan haklı nedenle fesih gerekçeleri arasında bulunmadığını, davacının sosyal açıdan tasvip edilemeyecek bu davranışının iş görme ediminin gereği gibi ifasını etkilediğinin de iddia ve ispat edilmiş olmadığını belirtmiştir. Ancak mahkemeye göre işverenin bu davranışı yapan davacı işçi ile iş ilişkisini sürdürmesi beklenemeyeceğinden, işverence yapılan feshin geçerli sebebe dayandığı kabul edilmelidir ${ }^{86}$. Kararda davacının davranışının sosyal ve ahlaki açıdan onaylanmayacak olsa dahi bu davranışın iş görme ediminin ifasında ne gibi olumsuzluk yarattığının ispat edilmediği belirtilmesine rağmen soyut bir biçimde bu durumda davacı işçi ile işverenin iş ilişkisini sürdürmesinin beklenemeyecek nitelikte olduğunun ifade edilmesi kanaatimizce isabetsiz olmuştur. Evvelce de belirtildiği üzere işyerinde yaşanan duygusal ilişkiler etik açıdan tasvip edilemeyecek nitelikte olsa dahi bu durum işin yürütümünü, normal işleyişini ve işyerindeki düzen ile uyumu bozacak nitelikte değilse geçerli fesih sebebi olarak kabul edilmesi mümkün olmamalıdır. İşyerinde yaşanan romantik ilişkilerin diğer çalışanlar tarafından konuşulması ve dedikodulara sebep olması çoğu kez ortaya çıkan bir sonuç olmakla birlikte soyut olarak bu durum geçerli sebeple feshe olanak sağlamamalı, dedikoduların işyerindeki huzuru ve işin yürütümünü olumsuz yönde etkileyip etkilemediği hususu dikkate alınmalıdır. Doktrinde Keser tarafından da isabetle belirtildiği üzere ortada fiili bir durum olmaksızın olası dedikodu ve

84 Yargitay 22.HD, 7794/11301, 24.03.2015 (Sinerji Mevzuat ve İçtihat Bilgi Bankası)

85 Doktrinde Keser, Yüksek Mahkeme’nin bu gibi hallerde işyerinde duygusal ilişki yaşayan taraflardan birinin ya da her ikisinin de evli olmasını, haklı sebeple fesih için bir kriter olarak değerlendirmeye yakın olduğunu ifade etmektedir. Keser (n 5) 26. 
olumsuzlukların varsayım olarak düşünülerek ve bu düşünceye dayanılarak yapılan bir fesih geçerli sebeple yapılmış bir fesih olarak değerlendirilemeyecektir ${ }^{87}$. Anayasa Mahkemesỉnin Esra Ünlü ve H.Ç başvurusunda belirttiği üzere iki çalışan arasındaki ilişkinin iş sözleşmesinin fesih nedeni olarak kabul edilebilmesi için işveren kesin deliller ile duygusal ilişkiyi ispatlamalı ve olumsuz etkilerinin neler olduğunu, bu etkinin işyerinin kapasitesi, işçinin ifa ettiği görevi, sicili, ilişkinin kim tarafından alenileştirildiği gibi hususları gözetip yeterli ve ilgili gerekçe ile açılayarak iş sözleşmesinin kendisi tarafından sürdürülmesinin mümkün olmadığını ortaya koymalıdır.

Daire, 01.07.2015 tarihinde verdiği kararında da dosya kapsamında bulunan tutanaklar ve davacıya ait aile nüfus kayıt örneği dikkate alındığında davacı ile işyerinde çalışan bayan iş̧̧i arasında ilişki olduğunun sabit olduğunu ve müşterek çocukları bulunduğunu, davacının evli olması da dikkate alındığında bu tür bir ilişki toplumsal olarak kabul edilmeyen bir davranış olsa bile iş sözleşmesinin feshi noktasında İş Kanununda sayılan haklı nedenle fesih gerekçeleri arasında bulunmadığını ancak işverenin bu davranışı yapan davacı işçi ile iş ilişkisini sürdürmesi beklenemeyeceğinden, işverence yapılan feshin geçerli sebebe dayandığının kabul edilmesi gerektiğini duygusal ilişkinin işyerinde olumsuz bir etkisi bulunup bulunmadığını dikkate almaksızın soyut bir biçimde ifade etmiştir ${ }^{88}$. 22. Hukuk Dairesi’nin kararları incelendiğinde genel olarak evli iş̧̧iler arasındaki deyim yerinde ise "yasak" ilişkiyi haklı değil ama geçerli fesih sebebi olarak kabul ettiği, bu sonuca ulaşırken ilişkinin işyerine olumsuz etkisi olmasını aramadığı görülmektedir. Daire işverenin böyle bir ilişkiye giren işçi ile iş ilişkisini sürdürmesinin beklenemeyeceğini açıkça ifade etmektedir ${ }^{89}$.

9. Hukuk Dairesinin de genellikle aynı yaklaşımı izlediği fakat bazen daha katı bir değerlendirme yaptığı görülmektedir. Daire’nin 2007 yılında verdiği karara konu olan olayda ise davacı işçinin evli olmasına rağmen, işyerinde çalışan bayan ile gönül ilişkisine girdiği, ailesinin gelmesi üzerine bayan işçinin ilişkisini bitirmek istediği, ancak davacının devam ettirmek için bayan çalışanı rahatsız ettiği, diğer bir işçi ile ilişkisi olduğu gerekçesi ile söylenti yaydığı ve bayan çalışanın diğer çalışan ile konuşmalarını cep telefonu ile kayda aldığı ve aleyhine kullandığı, bu davranışı nedeni ile şikayet edildiği, davacının davranışlarının işyerinde olumsuzluklara yol açtığı, iş sözleşmesi ilişkisinin işveren açısından sürdürülmesinin olanaksız olduğu, feshin davacının davranışlarından kaynaklanan geçerli nedene dayandığının sabit olduğu ifade edilerek işyerinde gönül ilişkisi sebebiyle ortaya

87 Keser (n 5) 23; Yazar tarafından işaret edildiği üzere işyerlerinde çalışan bekar bayan ve erkek iş̧̧iler arasında yaşanabilecek duygusal ilişkiler ile evli işçiler arasında yaşanabilecek duygusal ilişkiler arasında, bu ilişki iş ilişkisine ve işyerinde yürütülmekte olan işe olumsuz olarak yansımıyorsa temelde bir farklılık bulunmamakta; bu durum sadece tarafları ve aile hukuku kapsamında düşünüldügü takdirde bu tarafların eşlerini ilgilendirmektedir. İșverenin veya hakimin bu tür bir ilişkiyi yanlış ya da ahlaka aykırı bularak bir anlamda cezalandırmaya, İş Hukuku kapsamında düşünüldüğünde yetkileri bulunmamaktadır. Keser (n 5) 25.

88 Yargitay 22.HD, 17587/22860, 01.07.2015 (Sinerji Mevzuat ve İçtihat Bilgi Bankası).

89 Yargıtay bu görüşünü yeni bir kararında da sürdürmüştür. Daire’ye göre "Ancak dosya kapsamında bulunan tutanaklar dikkate alındığında davacı ile işyerinde çalışan bayan iş̧̧ arasında ilişki olduğu sabittir. Davacının evli olması da dikkate alındığında bu tür bir ilişki toplumsal olarak kabul edilmeyen bir davranış olsa bile iş sözleşmesinin feshi noktasında İş Kanununda sayılan haklı nedenle fesih gerekçeleri arasında bulunmamaktadır. İşverenin bu davranışı yapan davacı işçi ile iş ilişkisini sürdürmesi beklenemeyeceğinden, işverence yapilan feshin geçerli sebebe dayandığı kabul edilmelidir." Yargitay 22. HD, 20727/23324, 11.11.2019 (Sinerji Mevzuat ve İçtihat Bilgi Bankası) 
çıkan dedikoduların işyerinde olumsuzluklara yol açıp açmadı̆̆ını dikkate aldığı görülmektedir ${ }^{90}$. Daire’nin 2005 yılında verdiği kararda da somut olayda, evli olan davacının işyerinde evli bir bayanla birlikte iken kaçması ve birlikte olmasının, işçinin davranışlarından kaynaklanan ve işyerinde olumsuzluklara yol açan geçerli nedenler olacağını ifade ettikten sonra davacının bu davranışı nedeni ile aynı işyerinde çalışan eşinin şikayeti üzerine soruşturma yapıldı̆̆ı soruşturma safhasında geçici olarak başka yere atamasının yapıldığı ve bu durumun işyerinde olumsuzluklara neden olduğu belirtilmiştir ${ }^{91}$.

Buna karşılık 9.Daire’nin bazı kararlarında fiil işyeri dışında gerçekleşmiş olsa dahi aynı işyerinde çalışan evli işçiler arasında yaşanan duygusal ilişkilerin doğruluk ve iyi niyet kurallarıyla bağdaşmayacağı, ahlaki bakımdan da kabul görmeyeceğini göz önünde tutarak konuyu haklı fesih sebebi kapsamında ele aldığı görülmektedir. 2001 yılında verilen bir kararda evli olan işçinin işyerinde çalışan hemşire ile duygusal ilişkiye girmesi ve hatta işyerinde gebelik testi yaptırması ahlak ve iyiniyet kurallarına aykırı bir durum olarak değerlendirilmiştir ${ }^{92}$.

9. Hukuk Dairesi 2019 yılında verdiği kararda ise, evli ve 3 çocuk sahibi olan davacı işçinin, aynı işyerinde çalışan dava dışı evli bir kadın işçi ile gönül ilişki yaşadığının sabit olduğunu, davacının bu davranışının işin normal yürüyüşünü ve işyerindeki çalışma ortamını olumsuz etkilediğini ve davacının bu davranışının doğruluk ve bağlılığa aykırı olup, güven ilişkisinin zedelendiğini, işverenin iş sözleşmesini feshinin özel hayata müdahale olmadığı, bu nedenle işverenin feshinin 4857 sayılı Kanunun 25/II. maddesi kapsamında haklı nedene dayandığının anlaşıldığını ifade etmiştir ${ }^{93}$. Daire aynı yıl içerisinde verdiği bir başka kararda da aynı tutumu sergilemiş ve evli olan davacının davalı işyerinde çalışan bir kadın işçi ile gönül ilişkisine girdiği, işyerindeki bazı hareketleri, tutum ve davranışları neticesinde durumun çalışma arkadaşları tarafından fark edildiği, bu durumun çalışma arkadaşları nezdinde olumsuzluk yaratmasının yanı sıra ahlak ve adaba da mugayir olduğu, davalının bu durumda davacıyı çalıştırmasının beklenemeyeceği, davalının iş sözleşmesini fesihte haklı nedene dayandığı anlaşıldığından yazılı gerekçe ile kıdem ve ihbar tazminatına hükmedilmesinin hatalı olduğuna karar vermiştir ${ }^{94}$. Daire 2015 yılında verdiği kararında da benzer bir biçimde davacı kadın işçinin, aynı işyerinde çalışan evli olan Ü. ile duygusal bir beraberlik yaşamakta olup bu durum her ikisinin telefonundan çekilen mesajlar ile sabit olduğunu, aynı işyerinde çalışan ve kız kardeşi davacının duygusal beraberlik yaşadığı Ü. ile evli olan davalı tanığg ..e dava dışı .. tarafından bu ilişkiden söz edildiğini, buna göre somut olayın işyerinde çalışma düzenini bozduğu sabit olup işverence iş sözleşmesi haklı nedenle feshedildiği halde hatalı değerlendirme ile kıdem ve ihbar tazminatına hükmedilmesinin hatalı olup bozmayı gerektirdiğini ifade etmiştir ${ }^{95}$.

90 Yargitay 9.HD, 20397/32395, 5.11.2007 (Sinerji Mevzuat ve İçtihat Bilgi Bankasi)

91 Yargıtay 9.HD, 17355/2619, 31.01.2005 (Sinerji Mevzuat ve İçtihat Bilgi Bankası)

92 Yargitay 9.HD, 7288/10167, 14.6.2001 (Çil (n 40) 1985)

93 Yargıtay 9.HD, 10504/8673, 15.04.2019 (Sinerji Mevzuat ve İçtihat Bilgi Bankası).

94 Yargıtay 9.HD, 11196/14430, 27.06.2019 (Sinerji Mevzuat ve İçtihat Bilgi Bankası); Doktrinde Yıldız tarafından da haklı olarak belirtildiği üzere iş sözleşmesinin feshi açısından işyerinde olumsuzluklara neden olma dışında ahlaka ve adaba mugayır olma kavramının tercih edilmesi isabetli bir yaklaşım değildir. Yıldız (n 33) 11. 
Bununla birlikte Daire'nin 2015 yılında verdiği kararında, evli olan davacıya isnat edilen diğer işçi ile ilişkisinin, davacının eşinin şikayetine kadar işyerine yansımamış olup dosyadaki bilgi ve belgelere göre iş sözleşmesinin haklı nedenle feshini gerektiren bir durum da oluşmadığını, davalı tanıklarının da beyanlarında bunu dile getirdiğinden yapılan feshin haksız olduğunun kabulü gerektiğini, davacının bu davranışının 4857 sayılı İş Kanunu'nun 25/11. maddesinde yer alan nedenler içinde kalmadığını ifade ederek işyerine yansımamış olan ilişkilerin öğrenilmesi durumunu haklı fesih sebebi kapsamında değerlendirmeyerek Anayasa Mahkemesi ile paralel bir tutum izlemesi dikkat çekici niteliktedir ${ }^{96}$.

\section{SONUÇ VE DEĞERLENDIRME}

Birlikte çalıştıkları işyerinde zamanlarının çoğunu geçiren iki insanın tanışması, arkadaş olması ve aralarında duygusal bir ilişki yaşanması her zaman mümkündür. Sonuçta bu ilişkinin evlilik ile sonuçlanması mümkün olabileceği gibi hayatın normal akışında çeşitli nedenlerle sonucun evlilik olmaması hatta bazen ilişkinin olumsuzluk doğuracak şekilde sonuçlanması da olasıdır. İşverenlerin işçiler arasındaki duygusal ilişkilere ülkemizde olduğu kadar dünyada da farklı tepkiler verdikleri, bazen ast-üst konumunda olanlar bazen ise tüm çalışanlar arasında duygusal ilişkileri yasaklamayı deneyen işverenler olduğu, bazı durumlarda da bu ilişkilerin veya ilişkinin işyerine yansımasının tolere edilmediği dava konusu olan olaylardan anlaşılmaktadır. Bu tepkiler işçileri işten çıkarmaya kadar gidebilmektedir. Bu durumda işçilerin özel hayatının dokunulmazlığı ile işverenin işyerini verimli ve huzurlu yönetme hakkının çatıştığı ve sonuçta davalık olunduğu görülmektedir. Hukuk düzeni çatışan bu menfaatler arasında güç de olsa adil bir denge bulmalıdır.

İşçinin özel hayatı ile işyerinin menfaatleri arasındaki çatışmalarda her somut olaya tam olarak uyan tek tip bir çözüm geliştirmek güçtür. Yargıtay’n konuyla ilgili kararları incelendiğinde, her zaman istisnai kararlar bulunmakla birlikte, temelde duygusal ilişkinin işyerine olumsuz etkileri, ilişkinin çeşitli söz ve davranışlar ile işyerine ne ölçüde yansıdığı, ilişki içindeki işçilerin bekar veya evli olmaları gibi kriterlere göre bazı ölçütler geliştirildiği tespit edilmektedir. Yargıtay’ın genel olarak işyerinde huzursuzluk ve olumsuzluk doğuran ilişkileri ağırlığına göre haklı veya geçerli fesih sebebi olarak gördügü rahatça söylenebilir ki bu yaklaşım kanımızca da isabetlidir. Bu olumsuzluklara örnek olarak, özellikle üst ile astın ilişkisi sonucu verimsizlik-kaytarmacılık-adaletsizlik gibi sonuçların doğması ile ilişki içindeki kavgaların işyerine yansıtılması gösterilebilir. İlişki taraflarının olması gereken profesyonel yaklaşımı bir kenara atıp duygusal davranmaya ve işyerine zarar vermeye başlayan tutumlarına işverenin katlanması beklenemez.

Buna karşıllk işyerine hiçbir olumsuz etkisi olmayan bir duygusal ilişkinin işvereni ilgilendirmediği, işverenin ve mahkemelerin bir ahlak zabıtası görevlerinin bulunmadığı açıktır. İncelediğimiz Anayasa Mahkemesi kararlarında da AİHM içtihatlarına atıfla işçilerin işyerindeki davranış ve ilişkilerinin özel hayatın dokunulmazlığı kapsamında korunduğunun isabetli şekilde vurgulandığ1 görülmektedir. Bu alanda çözümü güç bir husus ise işçilerin birbirlerine işyerinde duygularını 
gösteren davranışlarda bulunmasıdır. Yargıtay’ın kararları incelendiğinde bunun genel olarak onaylanmadığ 1 söylenebilir. Anayasa Mahkemesi ise henüz bu konuya girme gereği duymamıştır. Somut olayda bu tip bir davranışın içeriği, ne ölçüde aleni ve rahatsız edici olduğu ile işyerinin nitelikleri de dikkate alınarak bir değerlendirme yapılması uygun olur. Aleni ve rahatsız edici olmayan davranışların, masum jestlerin fesih sebebi olması uygun olmayacaktır. Fakat temel olarak işyerinin çalışma yeri olduğu, işyerinde çalışanların profesyonel bir yaklaşımı ve ciddiliği korumasını beklemekte işverenin haklı bir menfaati olduğu da açıktır. Bu menfaat somut olayın koşullarına göre feshin geçerli kabul edilmesi sonucunu doğurabilir. Ancak feshin son çare olması ilkesine uygun olarak işverenin öncelikle işçilerini uyarması, olayın tekrarı halinde feshi düşünmesi olayın niteliğine göre daha uygun olabilir. Konuyla ilgili diğer bir sorun ise işverenin işçilerin duygularını gösteren davranışlarını nasıl tespit ettiği, özellikle bu konuda gizli gözetleme ile elde edilen bir delilin meşru olup olmayacağıdır ${ }^{97}$.

Yargıtay’n genel olarak işçilerden birinin veya ikisinin de evli olması durumunu ise ahlaka aykırı ve fesih sebebi olarak gördüğü söylenebilir. Bu durumda ilişkinin işyerine olumsuz etkisinin olması ve hatta işyerinde bilinir olması dahi aranmadan işveren feshi geçerli hatta bazen haklı kabul edilmektedir. Anayasa Mahkemesi ise incelediğimiz kararlarında tam aksi görüşü kabul etmekte, Yargıtay kararlarının özel hayat hakkını ihlal ettiğine karar vermektedir. Kanımızca da Anayasa Mahkemesinin konuya yaklaşımı daha isabetlidir. İşyerine hiçbir olumsuz yansıması olmayan bir duygusal ilişki, evlilik dışı "yasak" bir ilişki niteliğinde olsa dahi işyerine bir zarar vermediği sürece işvereni ilgilendirmez. İşverenin burada durumdan vazife çıkarıp ahlak bekçiliğine soyunması ve işçilerin iş sözleşmesini feshetmesi özel hayat hakkının ağır ihlalidir. Bu durumda feshin geçersizliğine hükmedilmelidir. İlişkinin işyerine olumsuz etkilerinin doğması halinde ise fesih geçerli kabul edilebilir. Bu konuda çözümü güç bir husus ise işyerinin bulunduğu çevre ve kültürel yaklaşımlar nedeni ile işyeri açısından bir zarar tehlikesinin doğması durumudur. Özellikle küçük bir yerde evli olan işçinin eşinin işyerinde olay çıkarması, zarar vermesi riski yüksek olabilir ve işverenden olası böyle bir tehlikeye aldırmamasını beklemek de isabetli olmaz. Ayrıca işletmenin dini-manevi amaçlı bir işyeri olması halinde de konuya farklı yaklaşılabilir. Kanımızca özel hayat hakkı ile işverenin menfaatleri arasındaki sınır bu durumda daha farklı çizilebilir. Ancak bu durumda dahi feshin son çare olması ilkesine uyulması zorunludur. İşveren fesihten önce başka çareleri denemeli, ilişki yaşayan evli işçisini uyarmalı, mümkün ise onaylarını alarak işçilerden birinin işyeri veya bölüm değişikliğine gitmelidir.

Temel ilke olarak, aynı işyerinde çalışmakla birlikte tamamen işyeri dişında duygusal ilişki yaşayan, bu ilişkilerini işyerine yansıtmayan ve işyerinde herhangi bir olumsuzluğa neden olmayan işçilerin özel hayat hakkının, işverenin menfaatlerinden önce geldiği kabul edilmelidir. Duygusal ilişki, işyerine olumsuz etkileri olmadığı sürece haklı veya geçerli fesih sebebi oluşturmaz. Anayasa

97 Gizli gözetleme tedbirine ilişkin olarak bkz. İlke Gürsel, İşçinin Kişisel Verilerinin Korunması Hakkı (1.Baskı Adalet Yayıncılık 2016) 373 vd; Gülsevil Alpagut 'İşyerinde Kamera Gözetlemesi ve AİHM Kararları ile Tespit Edilen Esaslar' in Prof.Dr.Kübra Doğan Yenisey (eds) Prof. Dr. Savaş Taşkent’e Armağan (On İki Levha Yayıncılık 2019) 276, 313 vd; Dilek Dulay Yangın, ‘Avrupa İnsan Hakları Mahkemesi Büyük Daire’nin İşçilerin Gizli Kamera İle İzlenmesine İlişkin 17 Ekim 2019 Tarihli Lopez Rıbalda ve Diğerleri Kararı’nın Değerlendirilmesi' (2020) 3 Çalışma ve Toplum 1709 vd. 
Mahkemesinin AİHM içtihatlarına dayanarak geliştirdiği içtihadı ile Yargıtay’ı da bu yöne sevk etmeye çalıştığ 1 tespit edilmektedir. Yargıtay’ın da genellikle bu ilkeyi gözetmeye çalıştığg ancak bazı durumlarda özel hayat hakkını yeterince gözetmeyen kararlar verebildiği görülmektedir. Gelecekte Yüksek Mahkemenin Anayasa Mahkemesi içtihadına tamamen uyması kanımızca yerinde olacaktır. Son olarak her durumda işverenin eşit davranma ilkesi ile de bağlı olduğu, özellikle de duygusal ilişki nedeni ile kadın işçiye erkek işçiden daha ağır bir yaptırım uygulama hakkının olmadığı, böyle bir durumda eşit davranma ilkesine aykırılık nedeni ile feshin haksız veya geçersiz kabul edilmesi gerekeceği açıktır.

\section{KAYNAKÇA}

Akyiğit E, İçtihat ve Açıklamalı 4857 Sayılı İş Kanunu Şerhi, I.Cilt (3.Baskı Seçkin Yayıncılık Ankara 2008)

Alpagut G, 'İşyerinde Kamera Gözetlemesi ve AİHM Kararları ile Tespit Edilen Esaslar’ in Prof.Dr.Kübra Doğan Yenisey (eds) Prof. Dr. Savaş Taşkent’e Armağan (On İki Levha Yayıncılık 2019)

Alp M, Çalışanın İşvereni ve İş Arkadaşlarını İhbar Etmesi - Çalışanın Hukuka ve Etik Kurallara Aykırılıkları İfşa Hakkı ve İhbar Borcu - (Whistleblowing) (1.Baskı, Beta Yayıncılık 2013)

Bakırcı K, İş Hukuku Açısından İşyerinde Cinsel Taciz (Birinci Baskı Yasa Yayınları 2000)

Boyd C 'The Debate Over the Prohibition of Romance in the Workplace' (2010) 97 (2) Journal of Business Ethics Springer, 326

Caniklioğlu N ve Akkaya M, 'Yargıtay Kararları Işı̆̆ında İşyerinde Kavga Sebebiyle İş Sözleşmesinin Feshi’ in Prof.Dr.Alpay Hekimler (eds) Festschrift für Otto Kaufmann Armağanı (Legal Yayıncılık 2021)

Civan O, İşçinin Yan Yükümlülükleri (1.Bası Beta Yayıncılık 2021)

Çelik N, Canbolat T, Caniklioğlu N ve Özkaraca E, İş Hukuku Dersleri (Yenilenmiş 34.Baskı Beta Yayıncılık 2021)

Çil Ş, İş Kanunu Şerhi II.Cilt (1.Baskı Turhan Kitabevi 2004)

Dulay Yangın D, Avrupa İnsan Hakları Mahkemesi Büyük Daire’nin İşçilerin Gizli Kamera İle İzlenmesine İlişkin 17 Ekim 2019 Tarihli Lopez Rıbalda ve Diğerleri Kararı’nın Değerlendirilmesi’ (2020) 3 Çalışma ve Toplum 1709.

Ergin H, 'İşçinin İşyerinde Çalışan Diğer Bir İşçiye Sataşması Nedeniyle İş Sözleşmesinin İşveren Tarafından Feshi' (2015) 34 Sicil İş Hukuku Dergisi 75.

Ergin H, 'İşyerinde Gönül İlişkisinin İş Sözleşmesinin Feshine Etkisi' (2016) 35 Sicil İş Hukuku Dergisi 68

Gürsel İ, İşçinin Kişisel Verilerinin Korunması Hakkı (1.Baskı Adalet Yayıncılık 2016).

Güzel A, 'İşletmesel Kararların Keyfilik Denetimine Tabi Olması ve Geçerli Nedenle Fesihte Son Çare (Ultima Ratio) Olma İlkesinin Gözetilmesi (Karar İncelemesi)' (2005) 1 Çalışma ve Toplum 163.

Keser H, 'İşçi Davranışları Kapsamında İş Sözleşmesinin Özel Hayat, Aile Hayatı ve Cinsel Yönelimler Sebebi ile İşverence Feshedilmesi' (2017) 37 Sicil İş Hukuku Dergisi 21.

Mollamahmutoğlu H, Astarlı M ve Baysal U, İş Hukuku (6.Baskı Turhan Kitabevi 2014)

Oral Ataç L ve Şahin Emir A, 'İş Hukuku Boyutuyla Örgütlerde Kayırmacılık' in Prof.Dr.Sevinç Köse ve Prof. Dr.Mustafa Alp (eds) Örgütsel Davranış ve İş Hukukuna Yansımaları (Seçkin Yayıncılık 2020).

Öktem Songu S, 'Bir Haklı Fesih Sebebi Olarak Sataşma’ (2018) 39 Sicil İş Hukuku Dergisi 120.

Ömüriş E ve Ehtiyar V. R, 'Örgütsel Yapılarda Romantik İlişkiler: Algılanan Güdüler ve Davranış Değişiklikleri Üzerine Bir Alan Araştırması' (2008) 16 Akdeniz İ.İ.B.F. Dergisi 21.

Özdemir E, 'İşyerinde Cinsel Taciz’ (2006) 4 Çalışma ve Toplum 84. 
Pärli K ve Vögtli J, 'Control and Sanction of Employees on the Basis of Conduct-A Question of Basic Labour (Human) Rights' (Spring 2020) Labour Law Journal 79.

Sevimli A, İşçinin Özel Yaşamına Müdahalenin Sınırları (1.Baskı, Legal Yayıncılık 2006),

Süzek S, 'İş̧inin Yetersizliği ve Davranışları Nedeniyle Geçerli Fesih’ Can Tuncay’a Armağan, (Legal Yayıncılık 2005)

Süzek S, İş Hukuku (Yenilenmiş 19.Baskı Beta Yayıncılık 2020)

Ugan Çatalkaya D, İş Hukukunda Ölçülülük İlkesi (1. Baskı Beta Yayıncılık 2019)

Yıldız G.Y, 'İşyerinde Yaşanan Gönül İlişkisinin İş Sözleşmesinin İşverence Feshi Açısından Değerlendirilmesi’ (2021) 3 (XXV) Ankara Hacı Bayram Veli Üniversitesi Hukuk Fakültesi Dergisi 4.

Yiğit Y, 'Yargıtay Kararları Işı̆̆ında İşyerinde Yaşanan Duygusal (Romantik) İlişkilerin İşverenin İş Sözleşmesini Fesih Hakkına Etkisi' (2020) 5 (1) Çankaya Üniversitesi Hukuk Fakültesi Dergisi 3778.

\section{Çevrimiçi Kaynaklar}

Sinerji Mevzuat ve İçtihat Bilgi Bankası (https://www.sinerjimevzuat.com.tr/) 